\title{
La escultura en Navarra en la primera mitad del siglo XV. Johan Lome y su círculo
}

\author{
Clara FERNÁNDEZ LADREDA \\ Universidad de Navarra \\ cladreda@unav.es
}

\begin{abstract}
RESUMEN
Se realiza una revisión de la obra de Jean Lome, escultor originario de Tournai, que, traído por Carlos III, desarrolló su actividad en Navarra durante la primera mitad del siglo XV y cuya realización cumbre, la tumba del rey, ha sido considerada uno de los conjuntos más importantes del periodo. Se trata de demostrar que -en contra de la teoría más difundida- Lome conoció la escultura borgoñona, especialmente la de la Cartuja de Champmol, en particular la de Claus de Werve, si bien la interpretó de modo personal. Se destaca la existencia de otro artista - por el momento anónimo-, que ha pasado casi inadvertido pese a su fuerte personalidad, colaborador de Lome, sobre todo en el sepulcro Garro, y que -en contraste con él-adoptó plenamente las formas sluterianas.
\end{abstract}

Palabras clave: escultura gótica navarra, Johan Lome, Cartuja de Champmol, escultura borgoñona.

\begin{abstract}
Here is a revision of the work by sculptor Jean Lome, born in Tounai and brought by Charles III, who developed his art in Navarre during the second half of the 15th Century and whose ultimate production, the Monarch's tomb, has been hailed as one of the most significant sculptural groups of the time. The aim is to prove that -in spite of the widespread theory- Lome was familiar with Burgundian sculpture, especially the_Chartreuse of Champmol, and particularly Claus de Werve's work, but chose to develop his own personal interpretation. Also, to highlight the presence of another artist -anonymous to date- who has gone unnoticed despite his strong personality, and worked with Lome, especially in the execution of the Garro sepulchre, and who -as opposed to Lome- fully adopted the sluterian forms.
\end{abstract}

Keywords: navarra gothic sculpture, Johan Lome, Chartreuse of Champmol, burgundian sculpture.

La relevancia de la figura de Johan Lome de Tournai, especialmente de su realización clave, la tumba del rey navarro Carlos III y su esposa Leonor de Castilla en la Catedral de Pamplona, ha sido ampliamente reconocida desde el artículo de Bertaux -punto de partida de todos los análisis posteriores-, hasta las publicaciones de fecha reciente -Didier-, pasando por la clásica monografía de Janke. En última instancia, unos y otros sitúan el sepulcro real dentro del selecto grupo de ejemplos de primera fila de la escultura funeraria europea del momento ${ }^{1}$.

1 E. BERTAUX, "Le mausolée de Charles le Noble à Pampelune et l'art franco-flamand en Navarre", Gazette des Beaux Arts, XL/2 (1908), pp. 90-111, lo considera uno de los monumentos del arte español que más interesan a la historia del arte europeo y el único conservado que se puede comparar a las tumbas ducales de Dijón. Por su parte R. DIDIER, "La sculpture, XIIème au XVIIIème siècle", Hainaut mille ans pour l'avenir, Amberes, 1998, p. 273 alude al alto crédito del que debió gozar Lomme en su época a partir del 
Sin embargo, la obra de este destacado artista y de su taller, y sus secuelas -que conforman el panorama de la plástica navarra de la primera mitad del siglo XVno ha sido objeto de una revisión seria desde hace más de 30 años, concretamente desde que en 1977 Janke sacara a la luz su monografía. Aunque esa publicación continúa siendo referente imprescindible para todo el que quiera llevar a cabo un acercamiento al tema, el paso del tiempo hace necesaria una nueva aproximación.

En efecto, los notables progresos en el terreno de la fotografía posibilitan disponer de repertorios de imágenes más extensos y de mejor calidad, que nos colocan en posición de hacer un análisis más profundo de los monumentos y unas comparaciones más sólidas, permitiendo llegar a conclusiones más correctas y apuradas sobre las relaciones existentes entre ellos, y sobre la cuestión de la participación de los colaboradores de Lome y la diferenciación de las distintas manos.

Además, durante las décadas transcurridas, el conocimiento de la escultura franco-neerlandesa, territorio del que procedían Lome y la mayoría de los integrantes de su círculo, ha experimentado grandes avances, que hacen posible -a su vez- progresar en una mejor comprensión del problema de la filiación y las fuentes de inspiración de estos artífices, permitiéndonos mostrar modelos concretos de sus realizaciones, algo que hasta el momento prácticamente no se había hecho.

Vamos pues, a revisar de acuerdo con estos parámetros los monumentos atribuidos a Lome y su taller, existentes en Pamplona: las tumbas del rey Carlos III de Navarra, del obispo de Pamplona Sancho Sánchez de Oteiza y del noble Leonel de Garro, y la puerta del crucero norte y la Virgen de las Buenas Nuevas, todas ellas en la catedral pamplonesa ${ }^{2}$.

\section{El sepulcro de Carlos III de Navarra y Leonor de Castilla ${ }^{3}$}

Es sin duda -como indicamos al principio- la obra cumbre de Lome y por ende está bien documentada. Contamos con bastantes datos, proporcionados por los $R e$ -

hecho de que fuera contratado por un cliente regio -Carlos III- para trabajar en un lugar tan lejano de su tierra natal -Navarra-; señala además la gran importancia relativa de su producción, ya que por las circunstancias, constituye el conjunto de escultura monumental y funeraria de un artista tournasiense de la primera mitad del XV más relevante que se ha conservado. R.S. JANKE, Jehan Lome y la escultura gótica posterior en Navarra, Pamplona, 1977, p. 55, considera el sepulcro real la mejor obra medieval conservada en Navarra (sic) y una de las obras maestras de la escultura funeraria del XV en general.

2 Existen otras obras vinculadas a Lome y su taller en Olite, Tafalla, Tudela y Viana, pero, por falta de espacio, hemos tenido que descartarlas, si bien esperamos publicar pronto un estudio complementario sobre ellas.

3 Carlos III dejó expresamente dicho en su testamento, datado en 1403, que deseaba que su sepultura se colocara en el coro catedralicio, refiriéndose a la parte oriental de la nave central, que es donde se solía situar este elemento. En un primer momento esto no fue posible, pues cuando se colocó el sepulcro en 1419 esa parte del edificio no se había construido, por lo que de momento se emplazó en el presbiterio, hasta el año 1509, en que, cumpliendo sus deseos, fue trasladado al coro -R.S. JANKE, op. cit., 1977, apéndice 1509-. En 1902-1903 la tumba fue desarmada y trasladada a la cocina, volviendo a su primitivo emplazamiento, donde se ha mantenido hasta hoy, en 1930 -J. GOÑI GAZTAMBIDE, Historia de los obispos de Pamplona, Pamplona, 1999, XI, pp. 71-79; y R.S. JANKE, op. cit., 1977, p. 55, nota 1. 
gistros de Comptos, que recogen la contabilidad real, publicados por autores anteriores $^{4}$, que sintetizaremos brevemente.

Fue ejecutado entre los últimos meses de 1413 y julio de 1419 . En lo relativo al límite inicial, la primera noticia de la realización de trabajos se remonta al 10 de octubre de 1413. En cuanto al final, entre mayo y junio de 1419 se colocó en su emplazamiento en la catedral pamplonesa, el 30 de junio se hizo el último pago a los mazoneros y el 18 de julio se abonó el dorado.

Se llevó a cabo en dos fases. La primera abarca desde el 10 de octubre de 1413 al 16 de junio de 1414, en que tenemos la referencia más tardía a mazoneros trabajando en la sepultura. La interrupción se debió a que a partir de ese momento pasan a trabajar en el palacio real de Olite. En suma, poco más de ocho meses, lo que ha llevado a pensar que debió hacerse muy poco, opinión reforzada por la gran cantidad de material -alabastro- que hubo que extraer para la segunda fase: quizás tan solo la parte arquitectónica, al igual que ocurrió con la tumba del duque de Borgoña, Felipe El Atrevido, y acaso no toda.

La segunda fase se extiende desde febrero de 1416, cuando según parece se reanudan las labores con la extracción de alabastro de las canteras de Sástago, hasta julio de 1419, en que se da por finalizado el sepulcro ${ }^{5}$. Ello supone -si descontamos el tiempo dedicado al arranque de la piedra- tres años o -sin descontarlo- tres años y seis meses. Resulta, por tanto, obvio que fue en esta etapa en la que se ejecutó la mayor parte del monumento.

Los registros nos informan asimismo sobre los artífices que intervinieron.

En primer lugar, por supuesto, Lome, que era el director de la empresa y percibía un sueldo fijo mensual de 23 libras y 10 sueldos, amén de lo que cobraba por realizaciones concretas, en cuyo caso podía ser bien por obra terminada, bien un jornal diario que al parecer era de 10 sueldos, como los artistas más cualificados. Procedía de los Países Bajos meridionales, la actual Bélgica, y tradicionalmente se ha supuesto que de Tournai ${ }^{6}$, topónimo que suele ir incorporado a su nombre, pero recientemente, se ha apuntado la posibilidad de que Lome fuera nativo de la localidad homónima -Lomme- ${ }^{7}$, cercana a Lieja, que actualmente es un suburbio de esta ciudad. Sus servicios fueron contratados por Carlos III en el curso de su último viaje a Francia (1408-1411) y la primera noticia de su presencia en Navarra

4 J.M. JIMENO JURIO, “Autores del sepulcro de Carlos III de Navarra", Príncipe de Viana, XXXV (1974), pp. 455-482; y R.S. JANKE, op. cit., 1977, pp. 37-53 y apéndice.

5 Desgraciadamente los libros correspondientes a 1416 y 1417 se han perdido.

6 El primero en indicar la procedencia tournaisiense, basándose en el recibo del pago del San Juan Bautista de 1411, fue E. BERTAUX, op. cit., 1908, p. 100.

7 J. MARTÍNEZ DE AGUIRRE, "La Rueda de la Fortuna: Carlos III de Navarra en París, de rehén a promotor de las artes", El intercambio artístico entre los reinos hispanos y las cortes europeas en la Baja Edad Media, León, 2009, p. 394. 
se remonta a agosto de 1411, cuando se le abona una escultura de San Juan Bautista hecha para el palacio de Olite.

Junto a Lome colaboraron otros artífices. Todos los cuales, salvo uno, ganan igual salario, 10 sueldos diarios, indicio de la misma categoría. Entre ellos habría que destacar a dos, Anequin de Sora y Michel de Reims -el primero originario quizás de los Países Bajos meridionales, como Lome, y el segundo francés-, que participan desde el inicio de la empresa hasta el final ${ }^{8}$ y que debieron compartir con Lome la mayor parte del peso del trabajo.

Otros tres, Johan de Lisla (Lille), Vicent Huyart y Johan de Borgoña, intervienen solo en la primera fase, que -como dijimos- fue muy breve, por lo que no debieron hacer mucho9.

Tres más colaboran únicamente en la segunda, Colin de Reims, Johan de la Garnia de Picardía y Johanto de Tolosa. De ellos, Colin de Reims es probablemente el que tuvo una participación mayor, ya que permaneció al menos un año ${ }^{10}$, mientras que Johan de la Garnia se une al equipo a principios de febrero de 1419, cuando faltaban solo cinco meses para terminar la tumba y debía estar prácticamente todo hecho, y Johanto de Tolosa, aunque presente prácticamente a lo largo de toda la fase,

8 Según las noticias documentales Anequin de Sora aparece trabajando por primera vez en la sepultura el 10 de octubre de 1413 y Michel de Reims el 22 de noviembre del mismo año -R.S. JANKE, op. cit., 1977, pp. 38 y 39, y apéndice 1413, 5 y 6-. Ambos cobran por última vez por sus trabajos en la sepultura el 30 de junio de 1419 -Ibidem, p. 52-. En el caso de Anequin de Sora J. IBAÑEZ FERNÁNDEZ y J. CRIADO MAINAR, "El maestro Isambart en Aragón: la capilla de los Corporales de Daroca y sus intervenciones en la catedral de la seo de Zaragoza", La piedra postrera. Simposium internacional sobre la catedral de Sevilla en el contexto del gótico final, 2. Comunicaciones, Sevilla, 2007, pp. 88-89, plantean la hipótesis de que se trate del mismo maestro que trabajó en la capilla de San Agustín de la catedral de Zaragoza, pero, dado que éste aparece trabajando en Zaragoza desde el 10 de enero y que nuestro Anequin en el mismo mes cobra por su labor en la tumba real, queda claro que se trata de artistas diferentes.

9 En el caso de Johan de Lisla, que parece haber trabajado a lo largo de toda la fase, pues se le cita el 10 de octubre de 1413 y figura de nuevo en el compto de 16 de junio de 1414 -R.S. JANKE, op. cit., 1977 , pp. 38 y 40 y apéndice 1413, 5-, el problema es que en otras ocasiones, en relación con trabajos en el palacio de Olite y en Santo Domingo de Estella, se menciona como carpintero -Ibidem, p. 45 y apéndice 1414, 17-. Vicent Huyard aparece trabajando el 10 de octubre de 1413 y se le cita por última vez el 9 de marzo de 1414 -Ibidem, pp. 38 y 39-40, y apéndice 1413, 5-, lo cual quiere decir que trabajó solo cinco meses. Juan de Borgoña aparece interviniendo por primera vez en el sepulcro el 10 de octubre de 1413 y debió trabajar toda la primera fase, pues cuando ésta se interrumpe lo vemos colaborando en el palacio de Olite en el que estará hasta el 19 de septiembre de 1414 -Ibidem, pp. 38 y 44 y apéndice, 1413, 5-. Parece ser que Vicent Huyart y Johan de Borgoña pasaron posteriormente -marzo/abril de 1418- a trabajar en la desaparecida capilla de San Agustín de la Seo de Zaragoza -J. IBAÑEZ FERNÁNDEZ y J. CRIADO MAINAR, op. cit., 2007, p. 89-.

10 Se documenta por primera vez el 10 de enero de 1418 y por última el 24 de febrero de 1419 -R.S. JANKE, op. cit., 1977, pp. 49 y 51-, pero hay que recordar que las cuentas de 1416 y 1417 se han perdido, por lo que pudo haberse incorporado antes. Se ha planteado la hipótesis de que posteriormente pasara a trabajar en la capilla de San Agustín de la seo zaragozana, donde a partir de marzo de 1419 se menciona un artista de igual nombre -J. IBAÑEZ FERNÁNDEZ y J. CRIADO MAINAR, op. cit., 2007, p. 90-. 


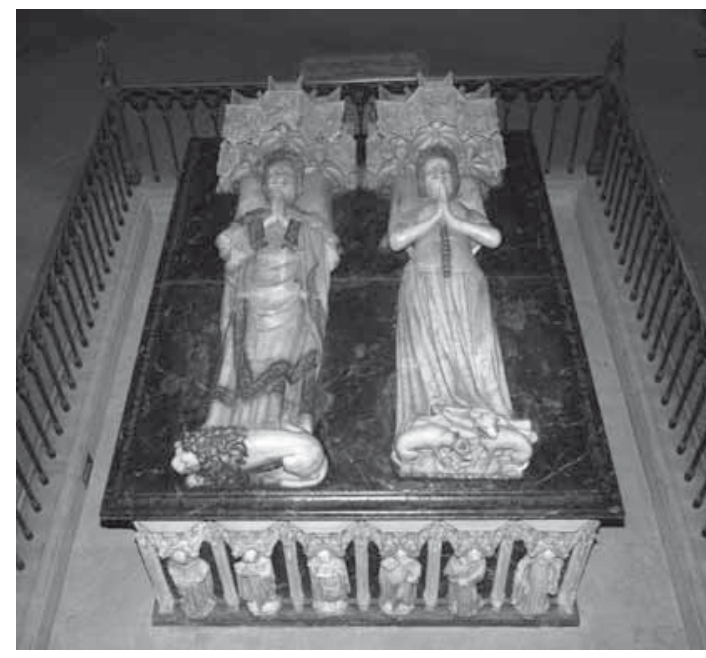

Fig. 1. Catedral de Pamplona, Sepulcro de Carlos III de Navarra y Leonor de Castilla, Conjunto. comenzó como aprendiz y nunca llego a ganar el mismo sueldo que los otros, claro indicio de su papel secundario $^{11}$.

La sepultura regia adopta la tipología de cama exenta (fig. 1). Está constituida por un paralelepípedo de piedra arenisca, que en origen estaba pintado de negro pero actualmente lo está de verde oscuro con vetas blancas imitando mármol ${ }^{12}$, sobre el que descansa una losa del mismo material y color de dimensiones ligeramente mayores con los bordes adornados por una moldura arquitectónica bajo la cual corre una hilera de hojas. Encima de la losa se sitúan los yacentes protegidos por grandes doseles arquitectónicos, en cuya parte superior se han grabado los epitafios, que en el caso del soberano -debido a su longitud-se prolonga por la moldura que remata la losa ${ }^{13}$. A lo largo de los costados se despliega el cortejo funerario, integrado por plorantes, cubiertos asimismo por doseles arquitectónicos. Todos estos elementos han sido labrados en alabastro, enriquecido con toques de color y dorado, que aún se conservan en las efigies.

Los yacentes son el elemento más relevante y llamativo del sepulcro, y centro del mismo. Se muestran frontales y hieráticos, con la mirada clavada en la bóveda y más allá en el cielo, y las manos unidas en actitud orante. Como se ha hecho notar, están concebidos como figuras erguidas y no acostadas, según pone de manifiesto el tratamiento de las vestiduras ${ }^{14}$.

Carlos III luce el atuendo ceremonial que llevó en su coronación, ajeno a la moda del momento. Se compone de una túnica de mangas ajustadas, larga hasta los

11 Aparece por primera vez el 2 de agosto de 1414 trabajando en el palacio real como aprendiz con un salario diario de 2 sueldos y 6 dineros, pero desde el 14 de marzo de 1418 hasta octubre del mismo año se le menciona trabajando en la tumba regia con un salario de 6 sueldos -R.S. JANKE, op. cit., 1977, pp. 43 y 49, y apéndice, 1414, 11-.

12 La afirmación de que en tiempos estaba pintada de negro en J. GOÑI GAZTAMBIDE, "El sepulcro de Carlos III el Noble”, Pregón, XXVIII, 1969, sin paginar, y R.S. JANKE, op. cit., 1977, p. 71 y apéndice 1755 , 2 y 3. La noticia de la incorporación de la pintura verde en E. BERTAUX, op. cit., 1908, p. 90, el autor no da fecha de la realización de dicha pintura, solo habla de la restauración reciente, pero, dado que su artículo está datado en 1908, no cabe duda que se refiere a la de 1902-1903.

13 Sobre los epitafios y sus errores R.S. JANKE, op. cit., 1977, pp. 59-63.

14 R.S. JANKE, op. cit., 1977, p. 65. 
pies, visible solo en las muñecas y la parte inferior, donde se encuentra surcada por pliegues tubulares; una sobretúnica, más corta y hendida por los lados, con escote redondo y amplio, y mangas anchas, adornada en los puños y bordes laterales e inferior por una greca azul sembrada de flores de lis doradas; y un manto, tipo socq o soccus ${ }^{15}$, empleado por los soberanos en las grandes solemnidades, abierto por el costado derecho y abrochado sobre el hombro del mismo lado, enriquecido con una orla dorada originariamente complementada con engastes de piedra. Resulta interesante señalar que el empleo de la indumentaria de la coronación en los yacentes de los reyes fue introducido por los monarcas franceses de la casa de Valois -estrechamente relacionados con el soberano navarro- y que en este punto la imagen del monarca navarro guarda un fuerte parecido con la del yacente de la tumba de Carlos V de Francia para San Denis (1364-1366) ${ }^{16}$.

La cabeza, pieza magnífica, de una calidad excepcional y tratada con gran delicadeza de modelado, se ha considerado un retrato del soberano ${ }^{17}$ y es posible que así sea. Su forma tiende a la cuadratura; el cutis es terso con ligeras arrugas en la frente, y más acentuadas en el rabillo de los ojos y la comisura de los labios; los ojos se mantienen abiertos y los párpados presentan bordes marcados por una doble incisión; la nariz, bien proporcionada, es fina y ligeramente aguileña, con los orificios nasales visibles; la boca, cerrada, ofrece unos labios finos y rectos; las orejas llaman la atención por el realismo y perfección de su labra. El pelo, color castaño, está cortado a la moda de la época, "en redondo" o "en escudilla"18. es decir, en forma de casquete, alto y recto sobre la frente -donde apenas resulta visible $-\mathrm{y}$ descendiendo en ligera diagonal por las sienes, pero siempre muy corto de modo que deja ver las orejas y la nuca. Ostenta corona, dorada, con aro adornado por motivos en relieve imitando hileras de perlas y piedras semipreciosas engastadas -hoy perdidas-, y remate de florones, que adoptan la forma de hojarasca típica de la época.

Doña Leonor, por el contrario, va ataviada a la moda. Luce una saya de escote de barco, con mangas estrechas y muy largas cubriendo parte de la mano, lisa y ajustada en el cuerpo y amplia y con pliegues en la falda, que es asimismo muy larga, de manera que oculta completamente los pies y aún arrastra por el suelo; encima lleva una sobrevesta abierta, prenda de lujo, dotada de amplio escote, ceñida al cuerpo marcando el busto, provista de grandes aberturas en los costados -que permiten ver la saya y el cinturón de orfebrería- y enriquecida con una tira de orfebrería que la

${ }_{15}$ F. BOUCHER, Historia del traje en Occidente, desde los orígenes hasta la actualidad, Barcelona, 2009, pp. 158-159.

${ }^{16}$ F. BARON, F. AVRIL et alii, Les Fastes du gothique. Le siècle de Charles V, París, 1981, nº 64, pp. 115-116. Conviene recordar que la apariencia de esta escultura era en origen muy distinta, pues ostentaba los atributos realizados en metal y estaba enriquecida con detalles de policromía, lo que acentuaba su parecido con la efigie de Carlos III.

17 R.S. JANKE, op. cit., 1977, p. 63.

${ }^{18}$ F. BOUCHER, op. cit., 2009, p. 159. 
atraviesa por el centro desde el escote al borde inferior ${ }^{19}$. Se trata de una indumentaria que encontramos frecuentemente en imágenes coetáneas o ligeramente anteriores de reinas y damas de la alta nobleza, entre las que habría que destacar la figura yacente de Juana de Borbon (h. 1376), esposa de Carlos V de Francia, para la citada tumba de San Denis ${ }^{20}$, o la estatua de la misma soberana formando pareja con su esposo, de discutida procedencia, conservada actualmente en el Louvre (1360-1384) ${ }^{21}$.

La cabeza de la reina presenta un contorno ovalado, con mejillas ligeramente mofletudas y una barbilla redondeada; el cutis es terso, sin arrugas; los ojos, la nariz y la boca son algo más pequeños que los de su marido, aquella es completamente recta y en ésta los labios son más carnosos y menos apretados. Como cabía esperar de una efigie femenina del momento, no nos hallamos ante un retrato sino ante una versión idealizada ${ }^{22}$. El tocado consiste en una redecilla, cuyos bordes se adornan con una tira de orfebrería con motivos muy similares a los del cinturón, sobre la que lleva una corona, idéntica a la de su esposo.

Ambas testas reposan sobre almohadones, abiertos por los costados -donde una red de hilos de oro deja ver el forro azul- y adornado por borlas asimismo doradas en los ángulos. En la parte superior, a los lados, lucían inscripciones doradas y pintadas, actualmente casi borradas, pero en las que en algún caso aún puede leerse el lema real Bone foy ${ }^{23}$. Los pies del monarca se apoyan, según costumbre, sobre una figura de león, tratada con gran realismo ${ }^{24}$. Los de la soberana sobre una pareja de perrillos que se disputan un hueso, tema de antigua tradición en el arte funerario, alusivo a la acción destructora del tiempo sobre la vida humana ${ }^{25}$.

Los yacentes se encuentran cobijados por doseles arquitectónicos -símbolo de la bóveda celeste- muy complejos. Están constituidos por una yuxtaposición de tramos de bóvedas de nervios octopartitas, sexpartitas y cuatripartitas ${ }^{26}$, sobre los que se despliega un alzado que se desdobla en dos niveles escalonados. Cada uno de ellos está formado por una serie de arcos apuntados -en el nivel superior se trata de auténticos ventanales con maineles-, con el tímpano adornado por tracerías, inscritos en arcos conopiales con decoración de hojarasca rematados en un florón, tras el cual se despliegan dos vanos apuntados, geminados, provistos

19 Ibidem, pp. 160 y 162.

20 F. BARON, F. AVRIL et alii, op. cit., 1981, nº 75, pp. 130-131.

${ }^{21}$ Ibidem, nº 68 , pp. 119-120. Ciertamente también podríamos mencionar las estatuas de la reina Isabel de Baviera, esposa de Carlos VI, y de Juana de Boulogne, mujer del duque de Berry, para la chimenea del palacio de Poitiers, datadas entre 1389 y 1393.

22 R.S. JANKE, op. cit., 1977, p. 66.

${ }^{23}$ R.S. JANKE, op. cit., 1977, pp. 65 y 67. Se conservan mejor las de la parte interior, que están a salvo de las manos de los visitantes, pero que solo se aprecian en fotos.

24 Ibidem, p. 66.

${ }_{25}$ Ibidem, pp. 67-68.

26 Ibidem, diagrama 1. 
asimismo de tracería. Los arcos del nivel inferior están separados por contrafuertes ornamentados con molduras y pináculos, y los del superior por arbotantes decorados con tracerías. Todas las tracerías están caladas, haciendo gala de gran virtuosismo, y presentan diseños basados en motivos de vejigas y triples lazos. El conjunto se completa con la procesión de plorantes, que se despliegan a lo largo de los costados, en total veintiocho, a razón de seis en los lados cortos y ocho en los largos. Están sustentados por peanas talladas con variados motivos -en su mayoría animalísticos, pero también vegetales y humanos- y cubiertos por baldaquinos arquitectónicos de plano trapezoidal, cuyos laterales presentan un diseño similar al del nivel inferior de los doseles regios, apeados en contrafuertes rematados por pináculos. Su localización no es la primitiva, ya que el sepulcro ha sufrido modificaciones y traslados ${ }^{27}$.

27 Al menos hubo tres traslados y dos restauraciones. Sobre el primer traslado, que tuvo lugar en 1509, vid. nota 3. En 1755 se llevó a cabo una primera restauración, que conocemos por un documento coetáneo -J. GOÑI GAZTAMBIDE, op. cit., 1969; y R.S. JANKE, op. cit., 1977, pp. 70-71 y apéndice 1755, 249-. El motivo fue que algunas de las piezas de alabastro - se supone que de los costados- estaban rotas, otras fuera de su sitio y otras faltaban, y el conjunto estaba ennegrecido por el polvo. En el curso de la misma se limpió y arregló la tumba, reemplazando los elementos que faltaban con otros hechos con piedra de diferente calidad. Ya por entonces se hizo una primera alteración en el emplazamiento de los plorantes, pues los dignatarios eclesiásticos -cardenales, obispos y canónigos-, que estaban en el lado correspondiente a la cabeza de los reyes se pasaron a los pies, siendo sustituidas por las piezas hechas en ese momento, pues la ubicación resultaba más discreta y se apreciaba menos su inferior calidad.

Un segundo desplazamiento y restauración tuvieron lugar en 1902-1903 -J. GOÑI GAZTAMBIDE, op. cit., 1999, pp. 71-76-, cuando se decidió llevar el cenotafio a otro lugar para colocar en su sitio la capilla de música. Inicialmente se desmontó en piezas sueltas y posteriormente se volvió a montar en la cocina capitular. Aprovechando el desarme, se acometió otra restauración, para la que curiosamente se esgrimen iguales razones que para la precedente -había perdido algunas figuras, otras estaban mutiladas y el conjunto estaba oscurecido por el polvo- y en la que se hizo lo mismo -arreglar las mutiladas, suplir las perdidas y limpiar todo-. Las fuentes dicen que "fueron dispuestas por su orden", dando a entender que se mantuvo la misma ordenación que tenían cuando el cenotafio estaba en la catedral, pero es inexacto, pues según el documento de 1755, las seis dignidades eclesiásticas habían sido trasladadas a los pies y en las fotos que muestran la tumba en la cocina, ninguna de tales esculturas ocupa ese costado. Esto, unido al tiempo transcurrido entre el desarme y el rearme, y al hecho de que -al parecer- el rearme se acometió para evitar que se perdieran piezas, hace pensar que más bien debió ser en ese momento cuando se perdió todo vestigio de la ordenación primitiva.

El tercer y último traslado tuvo lugar en 1930 y consistió en la vuelta de la tumba a su primitivo emplazamiento -J. GOÑI GAZTAMBIDE, op. cit., 1999, pp. 78-79-. Si cotejamos las fotos obtenidas cuando estaba en la cocina -E. BERTAUX, op. cit., 1908, pp. 93, 95, 99 y 101, y postales antiguas de L. Roisin y Viuda de Rubio- con el estado actual, constatamos que se produjeron nuevas alteraciones. Concretamente los plorantes que en la cocina estaban del lado de doña Leonor pasaron al de Carlos III y a la inversa, y en el caso del lateral de los pies se invirtió el orden de colocación -el primero por la izquierda pasó a ser el primero por la derecha, el segundo por la izquierda el segundo por la derecha y sucesivamente-. Si esto ocurrió entonces, cuando se disponía de documentos gráficos, no parece aventurado suponer que lo sucedido en el desplazamiento de 1902-1903 fue aún más serio.

Algunos de los plorantes llevan números escritos a lápiz o grabados, pero parecen recientes y -en cualquier caso- no hemos logrado descifrar su función. Como ya advirtieron autores anteriores -R.S. JANKE, op. cit., 1977, p. 72, nota 31; y C. MARTINEZ ÁLAVA, "La catedral gótica. Escultura", La catedral de Pamplona, 1994, I, p. 346- no parece que hagan referencia al orden original, pues, además de que ordenando las figuras en base a ellos el resultado carece de sentido, solo 12 de las 28 están numeradas. 
Siguiendo la pauta más habitual, todos son varones y pueden clasificarse en dos grupos: eclesiásticos y laicos ${ }^{28}$. Al primero pertenecen con seguridad los números $4,6,7,9$, $11,12,13,14,15,19,20$ у 21 , y muy posiblemente también el 16 y el 24 (fig. 2$)^{29}$. Al segundo los números $1,2,3,8$, $10,17,18,22,23,25,26,27$, 28 y quizás el 5.

Entre los eclesiásticos encontramos cardenales: 14 y 15 ; obispos: 7 y 20; canónigos: 6 y 9; y monjes de distintas órdenes.

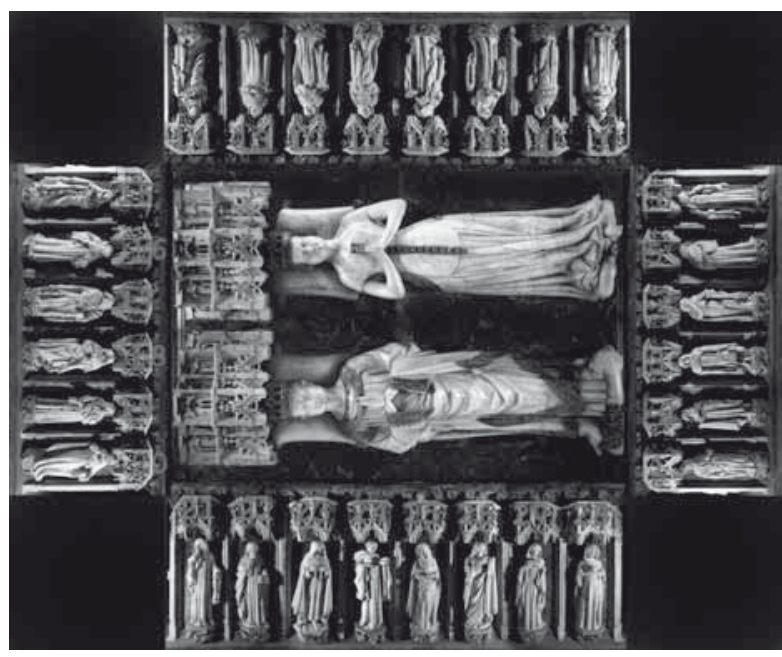

Fig. 2. Catedral de Pamplona, Sepulcro de Carlos III. Esquema de la localización de los plorantes.

Los laicos, como cabía esperar, ostentan todos atuendo de duelo, si bien con distintas variantes, en función de su relación con el difunto o su categoría. Así encontramos cuatro plorantes -10, 17, 22 y 26 - que lucen indumentaria de gran duelo, constituida por túnica larga y manto redondo cerrado; en cinco casos el grado de duelo está atenuado $-3,8,18,23$ y $25-$, como indican las prendas usadas, túnica larga con manto abierto por un lado $-8,18$ y $25-$ o túnica semicorta con manto -3

28 Aunque hemos examinado personalmente y con cuidado los plorantes, todo lo aquí dicho debe tomarse con alguna cautela, debido a los destrozos y restauraciones sufridas por estas figuras. Discrepando de lo afirmado por R.S. JANKE, op. cit., 1977, p. 72, quien consideró que solo dos estatuas -la 8 y la 27- habían sufrido graves daños y habían sido restauradas, compartimos la postura de C. MARTÍNEZ ÁLAVA, op. cit., 1994, p. 345, quien apoyándose en los testimonios de algunos autores -Víctor Hugo y Pascual Madoz-, que aluden a esculturas rotas y doseles caídos, y en lo recogido en la documentación anterior -vid. nota precedente-, que habla de figuras rotas y desaparecidas y menciona las restauraciones llevadas a cabo, piensa que las reposiciones fueron importantes y afectaron a cabezas y cuerpos enteros, y que resultan además difíciles de distinguir.

Por lo pronto, además de los señalados por Janke, un examen visual nos permite registrar al menos seis plorantes más que han experimentado restauraciones: los números 1, 3, 5, 7, 20 y 24. Generalmente, las restauraciones parecen haber afectado a cabezas y manos, pero en el plorante 20 da la impresión que se rehizo gran parte del brazo derecho. Desde aquí hacemos un llamamiento a las autoridades responsables para que decidan emprender un examen riguroso de los plorantes, desplazándolos de su lugar y aplicándoles las modernas técnicas disponibles, única manera de salir de dudas sobre este punto fundamental. La importancia de la obra lo merece de sobra. Esto permitiría de paso la realización de un dossier fotográfico exhaustivo y un estudio técnico.

29 Dado que desconocemos cual fue la localización original de los plorantes y que cualquier intento de reconstrucción de la misma no pasaría de hipotético, hemos establecido una basada en el único criterio objetivo y seguro del que disponemos: la localización actual. Partiendo del lado oriental y de su plorante más meridional, al que hemos otorgado el $n^{\circ} 1$ hemos seguido la dirección contraria a las agujas del reloj para terminar con el plorante del extremo oriental del lado sur, al que dimos el $\mathrm{n}^{\circ} 28$. Para una mejor comprensión incluimos una foto con la numeración superpuesta (fig. 2). 
y 23-; finalmente, otras tres esculturas -5, 27 y 28 - portan una vestidura larga, pero sin manto, propia de los grandes oficiales de la corte ${ }^{30}$.

Sería interesante poder reconstruir el orden original, aunque por el momento parece difícil hacerlo más que a grandes rasgos y como hipótesis. Lo único que sabemos con certeza es que, primitivamente, los dignatarios eclesiásticos -cardenales, obispos y canónigos- ocupaban el testero del cenotafio, es decir el lado correspondiente a las cabezas de los yacentes ${ }^{31}$, y que en cada uno de los tres grupos la composición de las dos figuras que lo integran se ajustaba al principio de simetría. A partir de ahí, solo caben suposiciones, aunque no es disparatado pensar que se adoptó el sistema empleado en la tumba de Felipe el Atrevido, duque de Borgoña, su presunto modelo, y que el cortejo seguía un orden jerárquico, encabezado por los citados dignatarios, tras los cuales irían los restantes eclesiásticos, cerrando la procesión los laicos, emplazados según su grado de duelo ${ }^{32}$.

Como ya advirtieron autores anteriores ${ }^{33}$, un atento examen de la totalidad de las esculturas nos permite agruparlas por parejas, cuyos componentes no solo pertenecen a la misma categoría religiosa o social, sino que, generalmente, guardan un estrecho parecido compositivo, ya que presentan posturas y ademanes similares o complementarios, y llevan atuendos iguales o semejantes, dispuestos de la misma manera. Con frecuencia se trata de dos figuras prácticamente idénticas a una de las cuales se ha aplicado el efecto espejo.

Comenzando por las autoridades eclesiásticas, que encabezaban la procesión y constituyen los ejemplos más claros de pareja ${ }^{34}$, tenemos a los cardenales (14 y 15), que repiten postura -en todo caso con una ligera diferencia en el ademán-, vestiduras y tratamiento de las mismas, pero invertidos ${ }^{35}$. Los obispos (7 y 20), uno con las manos entrecruzadas y cordón franciscano y el otro con libro y estola, son asimismo muy parecidos, como puede apreciarse cotejando las cabezas y la indumentaria. Otro tanto cabría decir de la pareja de capitulares (6 y 9), que resultan prácticamente igua-

${ }^{30}$ M. BEAULIEU, "Le costume français, miroir de la sensibilité (1350-1500)", Le vêtement. Histoire, archéologie et symbolique vestimentaires au Moyen Age, París, 1989, p. 260.

La 28 lleva una indumentaria muy similar a la del yacente de Philippe de Morviller -E. TABURETDELAHAYE (com.), Paris 1400. Les Arts sous Charles VI, París, Musée du Louvre 22 mars-12 juillet 2004, 225, pp. 359-360, presidente del parlamento de París, de fecha algo posterior h. 1426-1433 -túnica de mangas largas y ceñidas, sobretúnica de amplias bocamangas y una prenda de encima abierta por los lados hasta los hombros decorada con franjas horizontales en esa zona-, lo que hace pensar que se trata de algún personaje con importantes funciones judiciales o legislativas.

31 Así lo indica el documento relativo a la restauración de 1755 -vid. nota 27-.

32 A. Mc. MORGANSTERN, "Le tombeau de Philippe le Hardi et ses antécédents", Actes des Journées Internationales Claus Sluter (september 1990), Dijon, 1992, pp. 178-180.

33 R.S. JANKE, op. cit., 1977, p. 73.

34 Salvo indicación expresa en contrario, incluida en nota, nuestras parejas coinciden con las establecidas por Janke.

35 R.S. JANKE, op. cit., 1977, pp. 74-75, con cuyas observaciones coincidimos totalmente. 
les ${ }^{36}$, aunque invertidos, pues coinciden en postura -salvo en el ademán de enjugar las lágrimas usado solo en el 6-, vestiduras y plegado de las mismas.

En cuanto a los miembros de órdenes religiosas, las figuras 12 y 13, ataviadas ambas con hábito, manto y capucha, quedan emparejados sobre todo a través del atuendo. La relación entre los plorantes 19 y 21 se manifiesta en la similitud de posturas -en especial el ademán de enjugarse las lágrimas, si bien en uno de ellos se ha invertido el esquema con respecto al otro-, la coincidencia de los pliegues tubulares de la parte inferior y la semejanza de las cabezas. También las esculturas 16 y $24^{37}$ ofrecen una coincidencia muy llamativa por su singularidad dentro del conjunto, ya que son las únicas que llevan la cabeza destocada, y por añadidura sus posturas y actitudes son parecidas ${ }^{38}$. Pasando a los laicos, uno de los casos más claros de pareja son los plorantes 3 y 23 (fig. 3), que concuerdan en postura y ademanes, y en la indumentaria y su disposición -túnica semilarga y manto redondo levantado por delante-; los paralelismos alcanzan incluso a los detalles, como la tendencia a la ostentación -propia de
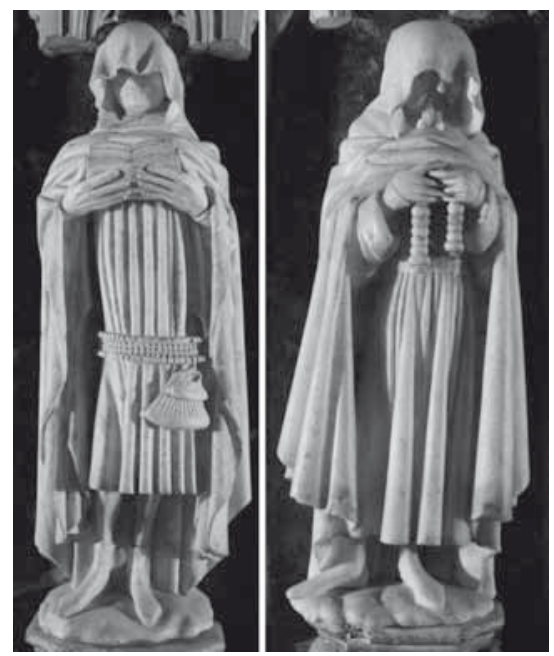

Fig. 3. Catedral de Pamplona, Sepulcro de Carlos III. Plorantes 3 y 23. su condición laica- manifestada además de igual modo -empleo de guarniciones de piel y cinturones decorados e incluso escarcela en el 3-. También resulta obvia la relación entre las figuras 27 y 28 , coincidentes en las posturas del cuerpo, cabezas y extremidades superiores, y en el empleo de un ropaje talar provisto de capucha y sin manto, surcado por pliegues tubulares verticales, que acentúan la esbeltez. Tampoco hay problemas para vincular las esculturas 10 y 18 , que cabría calificar como plorantes prototípicos con sus largos ropajes y sus capuchas cubriendo casi totalmente las caras, cuyos paralelismos se extienden asimismo a la posición de la cabeza y cuerpo -aunque el esquema se invierte-. Asimismo, podemos apuntar que otra pareja parece constituida por

36 Las observaciones que siguen están tomadas de R.S. JANKE, op. cit., 1977, pp. 77 y 78.

37 En este caso nos apartamos de Janke, ya que este autor emparejó la figura 16 con la 17 en base a una discutible tendencia al grosor de la primera que la emparentaría con la segunda-R.S. JANKE, op. cit., 1977, pp. 84-85-.

38 Como quiera que solo restan dos plorantes eclesiásticos, 4 y 11, por exclusión, parece lógico deducir que constituían pareja. También en este caso discrepamos de R.S. JANKE, op. cit., 1977, pp. 79 y 82, pues este autor relacionó el plorante 4 con el 25 y el 11 con el 8. Creemos que existe sin embargo un serio inconveniente para aceptar su hipótesis, pues tanto el plorante 25 como el 8 son indiscutiblemente laicos, con lo que, si seguimos su propuesta, nos encontraríamos con que ambas parejas estarían formadas por un eclesiástico y un laico, lo que rompería la tendencia vista hasta el momento, consistente en parejas cuyos miembros pertenecen a la misma categoría -dos cardenales, dos obispos, dos canónigos etc.-. 
las imágenes 1 y 8 , si bien en este caso conviene ser prudentes habida cuenta de la restauración sufrida por ambos ${ }^{39}$, pues las dos lucen la misma vestimenta dispuesta de idéntica manera -túnica semilarga provista de puños y largo manto abierto lateralmente para poder sacar los brazos, que levantan con las manos para dejar ver la túnica y las piernas-e, incluso, el plegado de la mitad inferior del manto es semejante.

De cara a un estudio estilístico, parece lógico considerar -como se ha venido haciendo- que la parte del monumento con mayores probabilidades de ser obra personal de Lome, que era el maestro principal y director de la empresa, son los yacentes, ya que se trata de las figuras más relevantes del conjunto. A partir de ahí, puede procederse a un análisis de los plorantes, cotejándolos entre sí y con las estatuas regias, para cuya comparación el elemento más útil son aparentemente las cabezas. En base a un atento examen de las mismas podemos distinguir dos grupos.

Uno estaría integrado por los eclesiásticos, que parecen estrechamente relacionados entre sí y con los yacentes ${ }^{40}$-o mejor dicho con el de Carlos III-, especialmente en lo relativo al tratamiento de los rostros. Formarían parte del mismo los cardenales (14 y 15), obispos (7 y 20), canónigos (6 y 9) y monjes $(4,11,12,13$, 16, 19 y 21) (fig. 4).

Efectivamente, los cardenales (14 y 15), obispos (7 y 20), uno de los canónigos (9) y uno de los monjes (16) muestran unas caras muy semejantes: con tendencia a la cuadratura, facciones carnosas, ojos horizontales bien abiertos, ojeras marcadas, barbilla redondeada y presencia de arrugas -particularmente visibles en el entrecejo, en los pliegues que arrancan de las ternillas nasales y en los de las comisuras de los labios-, que les confieren un aspecto flácido y a

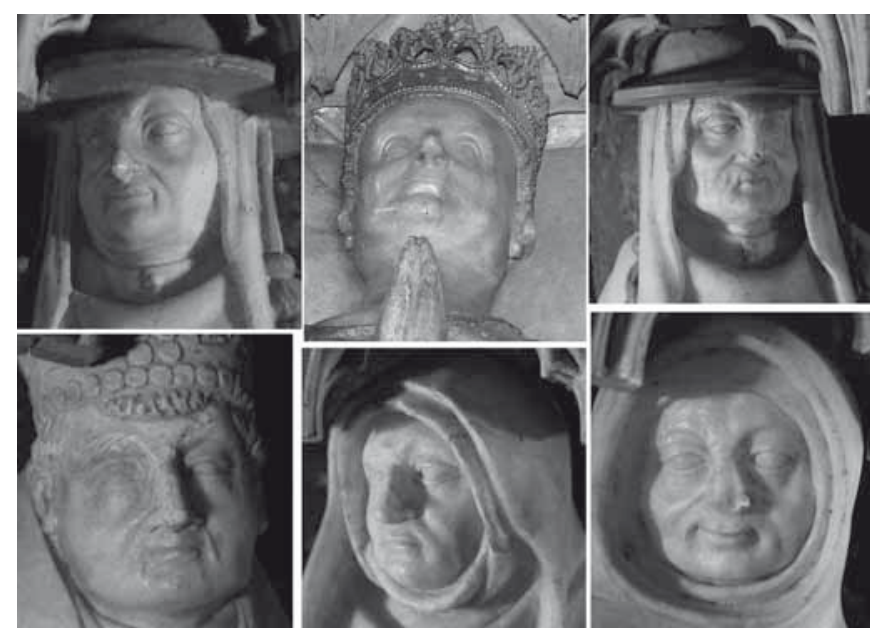

Fig. 4. Catedral de Pamplona, Sepulcro de Carlos III. Cabezas del yacente del rey y de algunos plorantes eclesiásticos. De arriba abajo y de izquierda a derecha plorante 14 (cardenal), Carlos III, plorante 15 (cardenal), plorante 7 (obispo), plorante 9 (canónigo) y plorante 11 (monje).

39 Vid. nota 28.

40 Este grupo coincide básicamente con el primer grupo analizado por R.S. JANKE, op. cit., 1977, pp. 73-79 constituido por los seis dignatarios eclesiásticos -cardenales, obispos y canónigos-y por cuatro plorantes más que relaciona con los yacentes $-12,13,8$ y $11-$. Hay sin embargo algunas diferencias entre nuestro grupo y el de Janke, concretamente que se excluye el plorante 8 y se incluyen los 4, 19 y 21. 
través de las cuales se pretende reflejar una edad ya avanzada. A su vez, el rostro de uno de los canónigos (9) -el más terso y menos personal y expresivo- se parece muchísimo al de dos de los monjes (11 y 13). Por su parte, el otro canónigo (6) presenta unas facciones menos carnosas, con rasgos más menudos y la frente surcada por arrugas y coronada por una breve cabellera someramente tallada, características que se repiten en los tres monjes restantes $(12,19 \text { y } 21)^{41}$.

También las similitudes con la cabeza de Carlos III, señaladas con anterioridad, resultan evidentes, en particular en el caso de los dignatarios eclesiásticos - cardenales, obispos y canónigos $-{ }^{42}$. Además, este mismo estilo es el que encontramos en el yacente del obispo Sánchez de Oteiza, muy posiblemente ejecutado también por Lome. Ello induce a pensar que se trata de piezas realizadas personalmente por el maestro o en las su intervención fue mayor, como ya se apuntó.

Un segundo grupo, que parece constituido exclusivamente por laicos, incluiría los plorantes $10,18,22,23,25,26$, y $28^{43}$. En efecto, si comparamos sus cabezas,

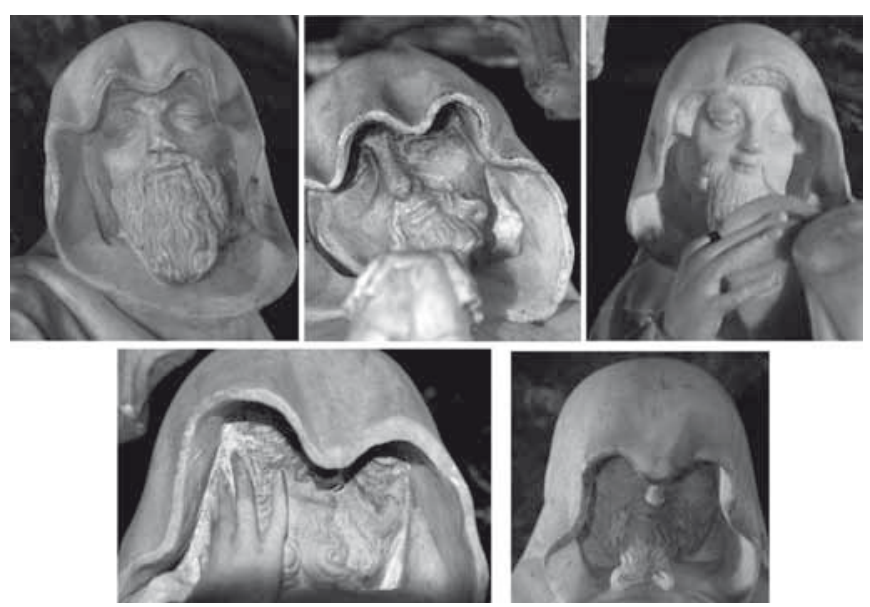

Fig. 5. Catedral de Pamplona, Sepulcro de Carlos III. Cabezas de plorantes laicos. De arriba abajo y de izquierda a derecha plorantes 25,18 , 26,10 y 23 . apreciamos la existencia de una estrecha red de relaciones entre ellas (fig. 5). En cambio, no se parecen ni a los yacentes, ni a los plorantes eclesiásticos.

De entrada, las estatuas 18,25 y 26 nos ofrecen una tipología idéntica y muy diferente de la de éstos: con caras más estrechas y alargadas, desprovistas de arrugas, barbadas -la barba está formada por un núcleo central más largo flan-

41 Excepcionalmente, la cabeza del plorante 4 tiene su punto de comparación en la del 22, que es un laico, con el que coincide además en el peculiar ademán de la diestra sujetando la barbilla.

${ }^{42}$ R.S. JANKE, op. cit., 1977, pp. 73-79. Incluso en dos de los casos, 9 y 11, las atribuye al propio autor de las efigies regias, es decir Lome.

43 En su mayoría este grupo coincide con el de los plorantes esbeltos de R.S. JANKE, op. cit., 1977, pp. 79-84. Pero hay algunas discrepancias. Por una parte, en nuestro grupo incluimos dos esculturas, la 8 y la 23 , que Janke no incluyó en sus plorantes esbeltos. Por otra, prescindimos de algunas que Janke colocó entre los plorantes esbeltos, por no encontrar puntos de contacto significativos entre ellas y las restantes componentes de nuestro grupo, como es el caso de las estatuas 2, 4, 19, 21, 24. De hecho tres de ellas, las 4, 19 y 21 las incluimos entre los plorantes relacionados con los yacentes. 
queado por sendos rizos más cortos que nacen del bigote o de la comisura de los labios-, con ojos oblicuos, párpados caídos -el borde del superior tiende a dibujar una línea en "S", muy característica-, nariz pequeña y delicada y el borde de la capucha surcado por múltiples ondulaciones; en conjunto presentan un aspecto mucho más juvenil que los eclesiásticos, compatible sin embargo con una expresión de tristeza que se plasma sobre todo a través de los ojos. Da la impresión de que las tres pueden atribuirse al mismo artífice. A su vez, la cabeza del plorante 18 puede ponerse en relación con las de las esculturas 10 y 23, si bien se detectan algunas discrepancias - la capucha oculta más la cara, el dibujo de las ondas del borde es ligeramente distinto y la barba adopta una configuración diferente, marcadamente bífida- y un ligero descenso de calidad. Creemos que ambas tallas se pueden adjudicar a un escultor, que se inspira en el anterior, aunque no hay que descartar que se trate del mismo. Por su parte, la testa de la figura 26 conecta con las de la 22 y la 28; con la primera coincide en la forma de la capucha, el peinado y los ojos, pero su peculiar gesto estorba las comparaciones, por lo que resulta difícil saber si nos enfrentamos con dos realizaciones de un único artista o si aquella sirvió de modelo a ésta; a la segunda se vincula por el tratamiento del peinado y la barba, pero la inferior calidad de la 28 pone de manifiesto que estamos ante una simple derivación.

Por último, tenemos un caso único, representado por el plorante 17, en el que el rasgo característico no es la cabeza -casi totalmente oculta por la capucha- sino el cuerpo o más específicamente su corpulencia y anchura de proporciones, no vista hasta el momento en ningún otro llorón, que invitan a considerarlo como una obra genuinamente sluteriana ${ }^{44}$.

En lo que se refiere a las fuentes de inspiración, el Cenotafio de Carlos III de Navarra y Leonor de Castilla parece haber tenido dos modelos fundamentales, si bien, como es propio de un autor de primera fila, no nos hallamos ante una copia servil.

De un lado, siguiendo una postura tradicional -con la que, sin embargo, no todos los especialistas están conformes- nos parece innegable la relación con el Sepulcro de Felipe el Atrevido ${ }^{45}$, duque de Borgoña, ejecutado entre 1384 y 1410

44 R.S. JANKE, op. cit., 1977, pp. 84-84 relaciona con esta escultura los plorantes 16, 3 y 23 e, incluso, atribuye los dos últimos al mismo escultor. Personalmente, no me parece que ninguno de ellos tenga esa anchura de proporciones típicamente sluterianas. De hecho, el 16 - a juzgar por la cabeza y como reconoció el propio Janke- se vincula con el yacente del monarca y lo hemos incluido en el grupo de los eclesiásticos. En cuanto, al 3 y el 23, si nos olvidamos del manto y nos concentramos en el cuerpo y las piernas, si se caracterizan por algo es por la esbeltez.

45 Entre los defensores de la relación con la tumba borgoñona cabe destacar a G. TROESCHER, Die burgundische Plastik des ausgehenden Mittelalters und ihre Wirkungen auf die europäische Kunst, Frankfurt am Main, 1940, I, p. 170; D. ROGGEN, "Prae-sluteriaanse, sluteriaanse, post-sluteriaanse nederlanse sculptuur", Gentsche Bijdragen tot de Kunstgeschiedenis, XVI (1956), p. 149 y, recientemente, R. DIDIER, Claus Sluter, Namur, 1993, p. 29, nota 10, y R. DIDIER, "La sculpture”, C. HECK, L'art flamand et hollandais. Le siècle des primitifs 1380-1520, París, 2003, p. 456.

Entre los discrepantes E. BERTAUX, op. cit., 1908, p. 111; R.S. JANKE, op. cit., 1977, p. 87; y J. MARTÍNEZ DE AGUIRRE, op. cit., 2009, pp. 399-400. 
y en el que intervinieron sucesivamente tres maestros, Jean de Marville (m. 1389), Claus Sluter (m. 1406) y Claus de Werve -si bien el papel principal recae en el segundo ${ }^{46}$ - . No solo es evidente la similitud de los elementos arquitectónicos -baldaquinos ${ }^{47}$ - sino también los parecidos entre algunos de los plorantes: concretamente los números $4 \mathrm{y}$ 22 de la sepultura navarra se pueden comparar con el 29 de la borgoñona, el 10 y el 18 con el 20 , el 17 con el 21, el 20 con el 5, y el 25 con el $35^{48}$ (fig. 6).

Ciertamente, existen también discrepancias, especialmente en lo concerniente a la introducción de rasgos novedosos en la tumba borgoñona -concepción de los baldaquinos como un solo espacio
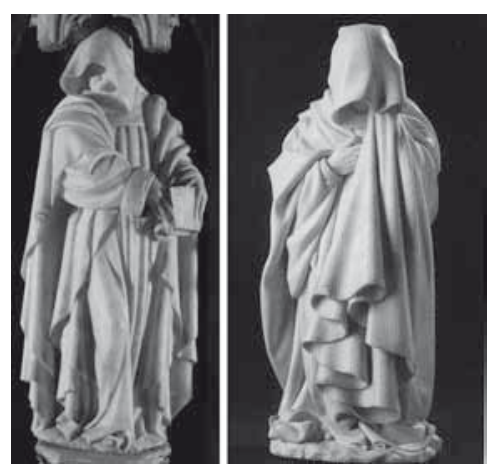

Fig. 6. Catedral de Pamplona, Sepulcro de Carlos III, plorante 17. Sepulcro de Felipe el Atrevido duque de Borgoña, plorante 21 (invertido). unido a modo de galería claustral y del cortejo funerario como una procesión coordinada, y tratamiento de los yacentes como figuras acostadas apreciable en la plasmación de las vestiduras-, ausentes en la navarra -donde nos encontramos con baldaquinos y peanas individuales, que impiden la unidad espacial y aíslan a los plorantes, y efigies dispuestas aún como figuras erguidas-, que dan lugar a que la primera represente una innovación de la fórmula tradicional -establecida por las sepulturas reales francesas de mediados del XIIIen tanto que la segunda supone un mero perfeccionamiento ${ }^{49}$. Sin embargo, esto no parece argumento suficiente para negar que Lome conociera el sepulcro ducal: el hecho de que un artista se inspire en una obra innovadora, pero se muestre más conservador que su prototipo, resulta relativamente frecuente en el arte y puede justificarse perfectamente por motivos variados, que van desde la menor capacidad

46 A. LIEBREICH, Claus Sluter, Bruselas, 1936, pp. 135-163; H. DAVID, Claus Sluter, París, 1951, pp. 107-127 y K. MORAND, Claus Sluter, Artist at the court of Burgundy, Austin, 1991, pp. 121-132 y 350-369; y S. JUGIE, The Mourners. Tomb sculptures from the Court of Burgundy, New Haven y Londres, 2010 , pp. 37-52. Generalmente, se atribuye a Sluter el diseño, la mayor parte de las arquerías y dos plorantes $-\mathrm{n}^{\circ} 39$ y 40-. Werve, que le habría seguido fielmente, habría realizado el yacente, el león, los dos ángeles y la mayoría de los plorantes.

47 Señalada ya por R.S. JANKE, op. cit., 1977, pp. 88-91, si bien sostenía que el modelo no había sido la tumba borgoñona sino algún monumento parisino y citaba en concreto la sepultura de Blanca de Navarra -segunda esposa de Felipe VI de Francia y tía de Carlos III- y de su hija Juana de Francia en San Denis. De todos modos resulta muy significativo que los dos casos aducidos por Janke como ejemplo de la dispersión de esta tipología de doseles -y de que, por tanto, Lome hubiera podido conocerla en otro lugar distinto de Dijon-, uno perteneciente al Museo Mayer van der Bergh de Amberes y el otro al Louvre, ambos hayan acabado siendo atribuidos ¡ al sepulcro del duque de Borgoña Felipe el Atrevido en Champmol! -S.N. FLIEGEL y S. JUGIE, Art from the Court of Burgundy. The Patronage of Philip the Bold and John the Fearless 136414, París, 2004, nº 82, pp. 226-229.

48 Particularmente interesante es el caso de la figura 20, un obispo, ya que se trata de una de las esculturas que Janke relaciona con los yacentes y, por tanto, con Lome, aunque sin llegar a atribuírsela.

49 R.S. JANKE, op. cit., 1977, pp. 57-58. 
del artífice hasta los deseos del comitente. Además, sabemos que al regreso de su tercer y último viaje a Francia (1408-1411), que es cuando se supone que Carlos III trajo a Lome, pasó por Dijon y nada impide que el escultor, aunque hubiera sido contratado en París, acompañara al soberano o, incluso, que éste lo hubiera contactado allís ${ }^{50}$. Finalmente, hay que advertir que -como tendremos ocasión de ver- no es el cenotafio regio la sola realización de Lome y su taller en que se constata el conocimiento de la plástica borgoñona de Sluter y sus seguidores.

El otro posible referente de la sepultura de Carlos III, que -curiosamente- ha pasado desapercibido hasta el momento -quizás porque solo se ha conservado uno de los yacentes y poco más- es la tumba de Carlos V, rey de Francia, y de su esposa, Juana de Borgoña, para San Denis, realizada entre 1364 y 1376 por André Beauneveu y, supuestamente, por Jean de Liège ${ }^{51}$. Efectivamente, encontramos coincidencias entre el sepulcro navarro y el francés, que afectan además a algunas de sus diferencias más notorias con el borgoñón y las explican, como el hecho de que se trate de un sepulcro doble, el empleo de doseles arquitectónicos sobre la cabeza de los yacentes con el epitafio grabado en ellos y la indumentaria de las efigies ${ }^{52}$. Además, si tenemos en cuenta las circunstancias personales de Carlos III, resulta muy lógico que uno de los modelos de su cenotafio fuera el sepulcro de un rey de Francia: su entronque con la dinastía real francesa de los Capetos -como bisnieto de Luis X-estaba más próximo que el de la familia de los Valois -a la que pertenecía Carlos V- y de hecho su padre Carlos II había aspirado de modo más o menos críptico a la Corona de Francia; había nacido y pasó gran parte de su vida en Francia; y su educación y sus gustos artísticos estaban estrechamente vinculados a ese país, como demuestran sus encargos, empresas y la nacionalidad de muchos de los artistas que contrató ${ }^{53}$; y el que el prototipo elegido fuera la sepultura de Carlos V se justifica porque era la más próxima en el tiempo ${ }^{54}$.

50 La segunda posibilidad es planteada por R.S. JANKE, op. cit., 1977, p. 88, pero la descarta. En este punto resulta muy interesante la noticia ofrecida por R. DIDIER, op. cit., 1993, p. 29, nota 10, sobre la existencia de un Jehan Lomme que era procurador de la Cartuja de Champmol en 1392 y 1393 y su hipótesis de que fuera pariente del escultor.

51 El resto desapareció a raíz de la Revolución francesa, el yacente que ha llegado hasta nosotros es el del rey, que se conserva en San Denis, pero conocemos el conjunto por un dibujo de la colección Gaignières. Vid. F. BARON, F. AVRIL et alii, op. cit., 1981, nº 64 y 75, pp. 115-116, 130.

52 La discrepancia de los baldaquinos fue señalada por R.S. JANKE, op. cit., 1977, p. 58 y la de la indumentaria por J. MARTÍNEZ DE AGUIRRE, op. cit., 2009, p. 400. Entre las coincidencias podríamos añadir una mas, el contraste de colores -negro para la cama sepulcral y blanco para el resto, si bien en el monumento francés el material empleado es mármol y en el navarro piedra pintada de negro y alabastro-, aunque es demasiado genérica para ser relevante - de hecho se da también con relación al sepulcro de Felipe el Atrevido de Borgoña-.

53 Menos convincente me resulta la relación con otros monumentos parisinos, como la tumba de Blanca de Navarra, esposa de Felipe VI, y de su hija Juana de Francia, y los yacentes de Pedro de Mortrain, hermano del propio Carlos III, y su esposa Catalina de Alençon -R.S. JANKE, op. cit., 1977, pp. 88 y 90-92-, pues a mi juicio solo presentan parecidos genéricos.

54 Emplazado en la capilla de San Juan Evangelista, hasta 1928 permaneció oculto por un altar y un retablo, cayendo en el olvido, y tras el descubrimiento hubo que proceder a una restauración, en el curso de la 


\section{El sepulcro de don Sancho Sánchez de Oteiza, obispo de Pamplona ${ }^{55}$}

Al contrario de la sepultura real no está documentado, lo que no obsta para que se haya atribuido a Lome y su taller, basándose en sus coincidencias formales con la tumba regia ${ }^{56}$, atribución que las propias observaciones corroboran. Además, los datos que conocemos del promotor y del artista avalan la teoría ${ }^{57}$. El primero desempeñó el papel de responsable de las obras del castillo de Olite, coincidiendo en el tiempo con el escultor ${ }^{58}$, por lo que necesariamente tuvo que conocerlo tanto a él como a su obra. Por añadidura, dentro del interés general por seguir la estela del sepulcro real, comisionando tumbas monumentales -común a las elites navarras del momento-, don Sancho se hallaba en una posición especialmente propicia para llevar la emulación de la empresa regia hasta el punto incluso de encargarla al mismo artífice, dada su reconocida voluntad de imitar al rey, expresada por él mismo cuando se declara "criado y hechura" suya.

La sepultura se labró mientras el prelado estuvo al frente de la seo iruñesa, entre 1420 y 1425 , periodo que coincide con la edificación de la nave y capillas meridionales, entre las que se encuentra la de San Juan Evangelista, a la que está íntimamente vinculada ${ }^{59}$. Como hipótesis, podemos proponer un marco más concreto, entre julio de 1419 y enero de 1422, etapa en el que se registra un paréntesis en la actividad conocida de Lome.

A diferencia del cenotafio regio, adopta la tipología de arcosolio. El hueco, emplazado bajo una ventana, se halla enmarcado por un arco apuntado, integrado por tres arquivoltas ligeramente abocinadas, al que se superpone otro conopial con decoración foliácea rematado por un gran florón central que se recorta sobre la ventana, todo ello flanqueado por sendas pilastras rematadas por pináculos. El ápice del arco apuntado se cierra con una tracería calada, colocada sobre un arco rebajado con el intradós decorado con arquillos semicirculares lobulados. El dibujo de la tracería se compone de un gran círculo central, que contiene tres cua-

cual se rehicieron las pilastras y pináculos laterales, se restauraron las esculturas del cortejo y la tracería del arca sepulcral, y se le incorporó el panel del frente de la misma, constituido con fragmentos procedentes del deambulatorio y el refectorio-R.S. JANKE, op. cit., 1977, pp. 117, nota 74, 119, nota 77 y 122, y apéndice 1929, 1930 y 1931-. En mi opinión, dichos fragmentos pertenecieron primitivamente no al sepulcro Oteiza -como se pensó- sino a uno de los sepulcros de arcosolio que había en la girola, posteriormente reconvertidos en puertas, más probablemente al de la puerta de la sacristía de los beneficiados.

55 R.S. JANKE, op. cit., 1977, pp. 119-124, da la impresión que más bien lo atribuye al taller.

56 C. FERNÁNDEZ-LADREDA, "Obispos y reyes, promotores de la catedral de Pamplona”, Cuadernos de la Cátedra de Patrimonio y Arte Navarro, n 2, Pamplona, 2007, p. 222.

57 J. GOÑI GAZTAMBIDE, op. cit., 1999, II, p. 476.

58 Fue promovida por el obispo como su capilla funeraria, como acredita la presencia de sus armas en ménsulas y clave, y además el arcosolio que alberga la tumba fue excavado en el muro meridional de la citada capilla coincidiendo con su edificación, como demuestra el trasdosado al exterior del mismo.

59 J. MARTÍNEZ DE AGUIRRE y F. MENÉNDEZ PIDAL, Emblemas heráldicos en el arte medieval navarro, Pamplona, 1996, pp. 53-57 y 250. 
drados curvilíneos con cuadrifolios inscritos, flanqueado por sendos escudetes rellenos con trifolios, todo ello articulado con lobulaciones de relleno trifoliadas. Sobre las enjutas, entre el arco conopial y los pináculos, campean los escudos del obispo Oteiza, enmarcados por octofolios, parcialmente recortados sobre la ventana. El conjunto resulta de gran sofisticación, debido especialmente al último detalle.

Este diseño arquitectónico, que encontraremos de nuevo en la tumba de Leonel de Garro y que se caracteriza por la incorporación de los escudos en las enjutas, se inspira en el de la gran ventana de la sala conocida como Cámara Luenga del Palacio viejo de Olite, en la que intervinieron Lome y sus colaboradores, siendo posiblemente ambas obras los primeros sepulcros navarros en adaptar la fórmula ${ }^{60}$.

La decoración plástica corre a cargo del yacente, que descansa sobre el sarcófago, escoltado por dos ángeles a la altura de la cabeza y con los pies apoyados

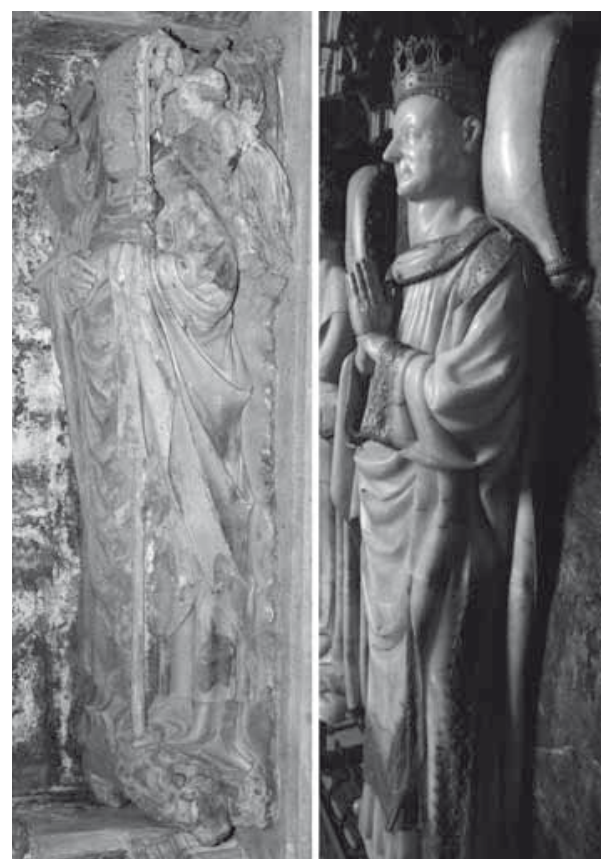

Fig. 7. Sepulcro del obispo de Pamplona Sancho Sánchez de Oteiza, yacente. Sepulcro de Carlos III, yacente. en un león; del cortejo funerario, que se despliega sobre las paredes del arcosolio, rodeando la efigie del difunto; y de sendas ménsulas, decoradas respectivamente con el león de San Marcos y el águila de San Juan, que sustentan la bóveda ${ }^{61}$. Actualmente, la monocromía de la piedra otorga al conjunto una apariencia confusa y dificulta la percepción de los detalles, pero parece probable que, primitivamente, las esculturas estuvieran policromadas y que tal policromía se completara con pinturas murales, que cubrirían el fondo del arcosolio, como ocurre en otras sepulturas navarras -Oteiza y Villaespesa de la catedral de Tudela, y Sánchez de Asiaín y Garro de la catedral de Pamplona-. El modelo de la tumba, con la presencia del cortejo fúnebre en torno al yacente, está sin duda en otro sepulcro episcopal de la propia seo, el de Miguel Sánchez de Asiaín $^{62}$, fechado entre 1357 y 1375, que

${ }^{60}$ El panel que cubre el frente de la caja con cuatro parejas de plorantes, enmarcadas por arcos conopiales, no pertenecía en origen al monumento - vid. nota 55-, que probablemente en esta zona ofrecería una ornamentación a base de círculos tangentes con cuadrilóbulos inscritos, similar a la de la tumba de don Leonel de Garro o a la de la vecina capilla de Santa Catalina.

${ }^{61}$ Aunque no de forma tan expresa, la idea fue apuntada por R.S. JANKE, op. cit., 1977, pp. 117 y 119.

62 Cercanía advertida ya por C. MARTINEZ ÁLAVA, op. cit., 1994, II, p. 349. 
era hasta entonces la más monumental y prestigiosa sepultura de obispo existente en la catedral iruñesa.

Formalmente, el tratamiento de las vestiduras del prelado y la figura de león se acercan mucho a los de la efigie de Carlos III $^{63}$ (fig. 7), en tanto que el rostro -carnoso, con el entrecejo fruncido, las mejillas flácidas, los finos labios y la potente mandíbula cuadrada- se relaciona con el de algunos de los plorantes eclesiásticos, especialmente 14 -cardenal-, 20 -obispo- y 16 ${ }^{64}$. Como quiera que estas obras, especialmente la imagen regia, se han vinculado con el propio Lome, no parece disparatado adjudicarle también la estatua episcopal ${ }^{65}$.

Por su parte, el interés de la pareja de ángeles que escoltan al obispo radica no tanto en que se trata de las mismas figuras que acompañaban al yacente de Felipe el Atrevido -al contrario de lo que sucede en la tumba real, en la que han sido reemplazados por doseles arquitectónicos-, como en sus semejanzas -especialmente en lo relativo al tratamiento de las exuberantes y movidas melenas, cuajadas de rizos, y de las alas- con alguno de sus equivalentes del pedestal del Calvario de la Cartuja de Champmol (1396-1404), realizado por Claus Sluter con la colaboración de su sobrino y discípulo Claus de Werve, si bien según la documentación fue éste último quien los labró entre 1399 y 1401: concretamente con los emplazados entre Moisés y David, Zacarías y Daniel, e Isaías y Moises ${ }^{66}$. De nuevo, como en el caso del cenotafio regio, entrevemos los vínculos con una realización del tándem SluterWerve, que refuerzan nuestra opinión de que Lome conoció su obra.

En el cortejo fúnebre se hace patente un descenso de calidad y un distanciamiento de los parámetros formales de la estatuaria de la tumba real ${ }^{67}$, por lo que parece indudable la intervención del taller. Si bien hay que tener en cuenta, por una parte, que se vio más afectado por la restauración y, por otra, la citada desaparición de la policromía, que perjudica su aspecto ${ }^{68}$.

${ }^{63}$ R.S. JANKE, op. cit., 1977, p. 120 lo compara con los plorantes 7 y 21, pero a mi juicio es mayor el parecido con los citados en el texto.

${ }^{64}$ R.S. JANKE, op. cit., 1977, p. 120; y C. MARTÍNEZ ÁLAVA, op. cit., 1994, II, p. 350 en cambio la relacionan con el taller.

65 A. LIEBREICH, op. cit., 1936, pp. 77-130, especialmente pp. 125-128; H. DAVID, op. cit., 1951, pp. 81-106, especialmente pp. 102-104; y K. MORAND, op. cit., 1991, pp. 91-120 y 330-349, especialmente, pp. $114-115$ y $333-334$, figs. 73 y $74 ; 77,80$ y 86 ; y 79 y 87.

66 Advertido tanto por R.S. JANKE, op. cit., 1977, pp. 121-122 como por C. MARTíNEZ ÁLAVA, op. cit., 1994, II, 350. Ambos sugieren que puede deberse a la diferencia de material -alabastro en el sepulcro regio y piedra caliza en el de la tumba episcopal-, teoría que no compartimos, porque no se aprecia en cambio en la puerta de San José, obra también de Lome y su taller, ejecutada en piedra.

67 El declive es aún más notorio en los plorantes del frente del sarcófago, pero -como ya indicamos en nota 55- no corresponden en realidad a este monumento.

68 Durante mucho tiempo fue adjudicado erróneamente a Leonel de Navarra, hijo natural de Carlos II, y como tal figura en las publicaciones antiguas. Está emplazado en el claustro, en el tramo NE, concretamente en el muro $\mathrm{N}$.

Pese a estar protegido por una reja, su estado deja que desear. Los daños afectan particularmente a los yacentes y sus complementos: las efigies tienen las cabezas dañadas - caras y tocado de la dama- y han per- 


\section{El sepulcro de Pere Arnaut de Garro y doña Juana de Beunza ${ }^{69}$}

Contamos en este caso con una referencia documental, recogida en el testamento del caballero, datado en febrero de 1422, en el que se expresa el deseo de ser enterrado en "la claustra de la iglesia catedral de Santa María de Pamplona en la sepultura nueva que yo he fecho fazer" 70 . Esto nos proporciona la identidad del promotor y destinatario de la tumba y un límite ante quem para su ejecución, ya que se dice que para entonces estaba hecha, aunque se da a entender que hacía poco. En cuanto al término post quem, parece lógico que sea posterior al cenotafio real, que estaba concluido y colocado en su lugar en junio de 1419, y que marcó el punto de partida para la floración de sepulcros monumentales en el reino navarro. De otro lado, el periodo comprendido entre julio de 1419 y enero de 1422, se solapa con un vacío en nuestras noticias sobre la actividad de Lome-como advertimos al tratar de la sepultura de don Sancho Sánchez de Oteiza-, que quizás se corresponda con la labra de estas dos tumbas. En efecto, la relación con Lome de, al menos, una parte de las esculturas del monumento -yacentes- fue admitida en publicaciones precedentes ${ }^{71}$ y nuestras propias observaciones nos han permitido corroborarla.

Su tipología y diseño coinciden, básicamente, con los del sepulcro del obispo Oteiza, con el que comparte el modelo, la ventana de la Cámara Luenga del palacio viejo de Olite -obra de Lome y su taller-, siendo, posiblemente, ellas dos las más antiguas sepulturas navarras en adoptar esta fórmula ${ }^{72}$. Sin embargo,

dido las extremidades de los dedos de las manos; de los cuatro ángeles que los escoltan, el más cercano a la pared ha desaparecido y el resto han perdido las cabezas y en algún caso parte de los brazos; el león en que apoya los pies el caballero está acéfalo y lo mismo ocurre con la pareja de canes a los pies de las dama. En el caso de los santos del fondo del arcosolio la conservación es mucho mejor, pero se detecta algún daño: San Antonio ha sufrido desgastes en la peana que han afectado especialmente a su atributo, el cerdo o jabalí, en el que apoya el pie izquierdo, que ha quedado casi invisible; San Juan Bautista ha perdido la cabeza del cordero; Santa Catalina parte de la rueda y el santo obispo -el peor conservado- la diestra, parte del báculo y, posiblemente la cabeza, sustituida por una moderna. En cuanto al Dios Padre que corona el nicho tiene la nariz rota y ha experimentado daños en la parte derecha del manto y posiblemente en el brazo del mismo lado.

Las pinturas murales también han sufrido mucho, pero aún se conserva parte. La policromía de los yacentes y sus complementos ha desaparecido y la de los santos no es la original, pero es muy posible que se conserven restos debajo de la actual. Por añadidura una espesa capa de polvo, alguna telaraña y cascotes cubren el conjunto, como acreditan las fotos.

La conclusión obligada, teniendo en cuenta - de un lado- la proporción del conjunto que se conserva y su interés y -de otro- su deplorable estado actual, es que resulta indispensable una restauración, que ponga freno al deterioro, elimine la suciedad y rescate en la medida de lo posible las pinturas y la policromía. Tras lo cual, quizás habría que proceder a eliminar la reja, que dificulta no poco la visibilidad, remplazándola por un sistema de protección que conjugue mejor esta y la seguridad.

69 R.S. JANKE, op. cit., 1977, pp. 152-153 y apéndice 1422, 12.

70 E. BERTAUX, op. cit., 1908, pp. 106-107 atribuye a Lome todo el conjunto. R.S. JANKE, op. cit., 1977, p. 159 solo los yacentes, pues aunque alude a los daños que han padecido y las dificultades que entrañan para su estudio, afirma que "corresponden más estrechamente a la tradición iniciada...por Lome y los ayudantes que continuaron trabajando en su estilo que las figuras de los santos".

71 J. MARTÍNEZ DE AGUIRRE y F. MENÉNDEZ PIDAL, op. cit., 1996, pp. 53-57.

72 C.R. POST, A history of spanish painting, Cambridge, Massachusetts, 1930, II, p. 110; y R.S. JANKE, op. cit., 1977, pp. 154-156. 
se aprecian diferencias, de las cuales la más notoria concierne a la tracería que cierra el tímpano del arco, cuyo dibujo resulta más avanzado, plenamente flamígero, y su apariencia más ligera, pues las secciones son más delgadas; además, la arquivolta apuntada cuenta con una decoración a base de motivos vegetales salpicados por animalillos, tallada con gran cuidado, presente en la ventana olitense pero ausente en la tumba episcopal; y el arco conopial se remata no con un florón sino con la figura de Dios Padre sobre una nube. Todo ello confiere al conjunto una calidad y delicadeza de ejecución superior a la del monumento precedente. Por añadidura, ha conservado restos de las pinturas murales que tapizaban el arcosolio y las enjutas - perdidas en el sepulcro de don Sancho-, que, a juzgar por las fotos y comentarios de autores anteriores y aún por los citados restos, eran de gran interés y calidad ${ }^{73}$.

La escultura está representada por los yacentes con sus complementos -colocados sobre la cama sepulcral-, un grupo de siete figuras sacras -emplazadas sobre el muro de fondo del arcosolio, a media altura, encima de una repisa corrida - y el ya citado Padre Eterno - que corona el arco conopial y preside el conjunto-.

Las efigies están en actitud orante con las manos unidas, igual que las de los reyes. Pere Arnaut luce idéntico corte de pelo "en escudilla" que el monarca, pero su atuendo difiere, ya que va vestido como corresponde a un caballero; ostenta armadura con la espada ceñida en el costado izquierdo y sobre ella lleva una huca hasta medio muslo, prenda corta de encima, muy a la moda - pues surge a principios del $\mathrm{XV}$ - y que, precisamente, estaba pensada para lucir sobre la armadura ${ }^{74}-$; rodea su cuello con un collar de hojas de castaño. La indumentaria de doña Juana se aparta asimismo de la de la soberana, pues consiste en una hopalanda, vestido amplio y largo, ceñido al talle por un cinturón, pero cuyos pliegues tubulares muy regulares se cosían en la propia prenda, provisto de cuello elevado por detrás denominado carcaille, con escote en "uve" y mangas amplias y colgantes ${ }^{75}$; se adorna con un característico tocado de cuernos ${ }^{76}$ completado con un velo; en torno al cuello ostenta un collar o cadena de dos vueltas del que pende un medallón. Las cabezas descansan sobre almohadones y se encuentran flanqueadas por parejas de ángeles -cuyas testas desdichadamente se han perdido-, vistos ya en la sepultura de don Sancho. El caballero apoya sus pies sobre un león y la dama sobre dos canes, como los yacentes reales.

Pese a su mala conservación, la cabeza de Pere Arnaut de Garro nos permite apreciar sus semejanzas con la de Carlos III: contorno tendente a la cuadratu-

\footnotetext{
73 F. BOUCHER, op. cit., 2009, p. 158.

${ }^{74}$ Ibidem, pp. 156 y 162.

75 Ibidem, p. 163.

76 R.S. JANKE, op. cit., 1977, pp. 158-159.
} 
ra, sutiles arrugas surcando la frente, patas de gallo en el rabillo de los ojos, pliegues en torno a la boca y tratamiento naturalista de las orejas ${ }^{77}$; desdichadamente el estado del rostro de su esposa es aún peor e impide toda comparación con la de doña Leonor. Podemos comprobar, en cambio, que el atuendo y tocado de doña Juana se repite en la efigie de doña Teresa Palomeque ${ }^{78}$, procedente de su tumba en Santo Domingo de Estella -hoy en el Museo de Navarra-, fechada entre 1424 y $1430^{79}$, con la que también comparte el detalle de los ángeles flanqueando la cabeza ${ }^{80}$; de hecho ambos monumentos han sido atribuidos al mismo taller. Más relevante es su parecido con la estatua de la reina doña Blanca, hija y sucesora de Carlos III, que flanquea la puerta de entrada del claustrillo de la iglesia de Santa María de Olite ${ }^{81}$, en construcción hacia 1432 con financiación de la propia soberana ${ }^{82}$ : no solo el tocado y vestido coinciden -salvo pequeños detalles-, sino que el tratamiento de las telas y el plegado son iguales ${ }^{83}$; la trascendencia de estas concordancias reside en que tanto esta escultura como la Virgen con la que forma pareja han sido adjudicadas al propio Lome ${ }^{\square}$ Por su parte, los ángeles guardan una evidente similitud con sus equivalentes del sepulcro Oteiza, aunque, una vez más, sus pérdidas nos impiden apurar el cotejo. Esta red de relaciones, en especial las establecidas con el cenotafio real y la imagen de doña Blanca, parece confirmar la adjudicación de los yacentes a Lome.

El interés de las restantes figuras -el grupo del Calvario, y las tallas de San Antonio, San Juan Bautista, Santa Catalina y Dios Padre ${ }^{84}$-, dejando a un lado su excelente calidad avalada por su buen estado de conservación, radica en su vinculación con obras de los dos escultores borgoñones más representativos, Claus Sluter y Claus de Werve.

\footnotetext{
77 Las coincidencias fueron ya advertidas por R.S. JANKE, op. cit., 1977, p. 162, que las atribuyó al mismo taller.

78 J. MARTÍNEZ DE AGUIRRE y F. MENÉNDEZ PIDAL, op. cit., 1996, p. 161.

79 Por desgracia, el yacente de su marido, don Gonzalo de Baquedano, se ha perdido, por lo que no resulta posible cotejarlo con el de Pere Arnaut.

80 Actualmente y para evitar que continúe el deterioro ha sido retirada al interior de la iglesia. La medida es acertada, pero debió haberse tomado con anterioridad, pues para entonces había desaparecido prácticamente la cara. Por ello, para su estudio y cotejo, es mejor recurrir a las fotos del Archivo Príncipe de Viana, algunas de las cuales fueron publicadas por R.S. JANKE, op. cit., 1977, figs. 129, 131 y 132.

81 J. MARTÍNEZ DE AGUIRRE y F. MENÉNDEZ PIDAL, op. cit., 1996, pp. 217-218.

82 R.S. JANKE, op. cit., 1977, pp. 174-175 aludió al parecido, pero de pasada, sin enfatizar y sin sacar las conclusiones pertinentes. En cuanto a las diferencias, que como cabría esperar van en el sentido de una mayor suntuosidad, ya que se trata de la reina, podemos citar las siguientes: el cuello de la hopalanda ha sido retirado hacia atrás y se deja ver la piel que forra sus mangas, la cadena de doble vuelta se ha alargado de modo que alcanza la cintura y se ha incorporado un collar de hojas de castaño.

83 Ibidem, p. 176.

${ }^{84}$ Omitimos del análisis la figura del obispo, cuya calidad nos parece inferior. De todos modos, los restantes análisis nos proporcionan elementos suficientes para apoyar nuestra tesis de la vinculación de estas esculturas con obras borgoñonas.
} 
La Crucifixión -integrada por Cristo, la Virgen y San Juan Evangelista- ${ }^{85}$ deriva del famoso Calvario que presidía el cementerio de la Cartuja de Champmol ${ }^{86}$, ejecutado entre 1396 y 1399 por Claus Sluter con la colaboración de Claus de Werve, del que por desgracia únicamente nos han llegado algunos fragmentos ${ }^{87}$.

En el caso del Crucificado, no solo los restos del ejemplar cartujano conservados - cabeza y torso, y piernas de la rodilla para abajo ${ }^{88}$ - se parecen a sus equivalentes del navarro, sino que éste ostenta un halo que coincide justo con la intersección de los brazos de la cruz y lleva un titulus sobre la cabeza, como ocurría en la imagen borgoñona. Ciertamente, cabe tener en cuenta otro referente -que acaso sirviera de intermediario-, el Cristo del monasterio de San Benigno de Dijon, atribuido a Claus de Werve y fechado en el primer cuarto del XV, basado en el de la Cartuja ${ }^{89}$. Sabemos, en efecto, que gozó de popularidad entre los artífices borgoñones, como acredita la existencia de una serie de secuelas: Puley, Roche-Vanneau y Châteauneuf- $-^{90}$.

Respecto a la Dolorosa, su relación con la Virgen del Calvario de Champmol ${ }^{91}$ queda demostrada por su estrecha semejanza con toda una serie de tallas borgoñonas que la tuvieron como modelo ${ }^{92}$ : Prémeaux, Mouthier-le-Vieillard, Baumeles-Messieurs y Flavigny-sur-Ozerain -dos- y un ejemplar del Museo Dahlem de Berlín $^{93}$ (fig. 8).

${ }^{85}$ Una copia mediocre de este Calvario preside una tumba anónima emplazada en la capilla de Santa Catalina-C. MARTÍNEZ ÁLAVA, op. cit., 1994, I, pp. 352-353-.

${ }^{86} \mathrm{El}$ hecho fue advertido por G. TROESCHER, op. cit., 1940, volumen de texto, pp. 114 y 170. Pero, curiosamente, quizás por la fecha de aparición de la publicación o por el idioma, ha pasado inadvertido para los historiadores de arte españoles e, incluso, para el propio Janke.

${ }^{87}$ Ciertamente, se ha conservado la base, el famoso Pozo de Moisés, pero aquí me estoy refiriendo al Calvario propiamente dicho, compuesto por el Crucificado, la Virgen, San Juan y la Magdalena.

Sobre esta obra A. LIEBREICH, op. cit., 1936, pp. 77-130; H. DAVID, op. cit., 1951, pp. 81-106, especialmente 104-105; y K. MORAND, op. cit., 1991, pp. 91-120 y 330-349, especialmente p. 115, 335-337 y 342-348. La colaboración de Werve está documentada para el Cristo y la Virgen.

${ }_{88}$ Vid. bibliografía citada en nota anterior y S.N. FLIEGEL y S. JUGIE, op. cit., 2004, nº 77 y 78, pp. 220-221.

89 P. QUARRÉ, "Le Christ en croix de Saint Benigne de Dijon”, La Revue du Louvre et des Musées de France, 16 (1966), pp. 5-12; y S.N. FLIEGEL y S. JUGIE, op. cit., 2004, nº 123, pp. 330-331.

90 Ibidem.

${ }^{91}$ La relación con la Virgen del Calvario de Champmol fue ya apuntada por A. LIEBREICH, "Le Calvaire de Champmol et l'art de Sluter: reconstitution du Calvaire", Bulletin Monumental, XCII (1933), p. 467; y A. LIEBREICH, op. cit., 1936, p. 96, nota 6. La primera cita fue recogida por R.S. JANKE, op. cit., 1977, p. 157, nota 54, pero no le concedió demasiada importancia, como prueba el que la relegara a nota, y haya pasado totalmente inadvertida.

92 K. MORAND, op. cit., 1991, pp. 346-347 ofrece el listado de obras derivadas del Calvario de Champmol, indicando a qué autor se debe el establecimiento de tal relación.

93 Para la de Prémeaux: P. QUARRÉ, Claus de Werve, Imagier des Ducs de Bourgogne, Musée de Dijon, 1976, no 43-44, pp. 44-45 y S.N. FLIEGEL y S. JUGIE, op. cit., nº 88, pp. 246-247; para la de Flavigny que nos ha llegado sola: P. QUARRÉ,op. cit., 1976, n 42, p. 44; y S.N. FLIEGEL y S. JUGIE, op. cit., 2004, n ${ }^{\circ}$ 87, pp. 245-246; para las de Mouthier-le-Vieillard, Beaume-les-Messieurs y la de Flavigny que forma pareja con San Juan: G. TROESCHER, op. cit., 1940, volumen de texto, p. 111 y volumen de láminas, 

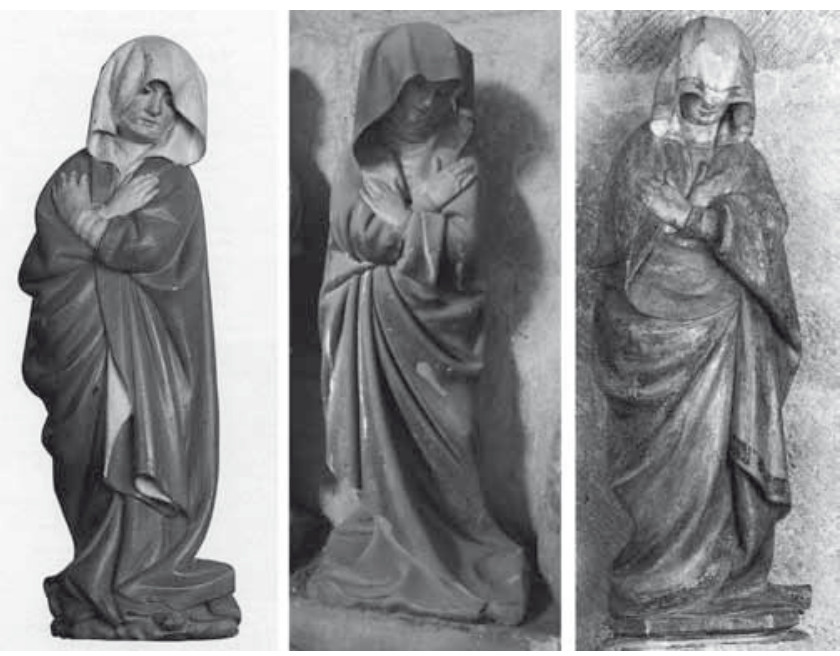

Fig. 8. Sepulcro de Leonel de Garro y Juana de Beunza, Virgen del Calvario (centro). Vírgenes de Prémeaux (izquierda) y Flavigny-surOzerain (derecha).
Contra lo que cabría esperar, el San Juan Evangelista no se parece, en cambio, gran cosa a los de los Calvarios citados de Prémeaux, Mouthier-le-Vieillard, Baume-les-Messieurs y Flavigny-sur-Ozerain ${ }^{94}$. Pero resulta posible ponerlo en conexión con las esculturas de los tres santos gemelos de Capadocia -Eleusipo, Meleusipo y Espeusipo- de San Geosmes, que han sido relacionadas con Claus de Werve ${ }^{95}$. Al primero se asimila en la disposición

del manto y los ademanes, y al segundo en el tratamiento de la cabeza. En cualquier caso, la presencia de una estatua del apóstol similar a la navarra, pero más tardía (segunda mitad del XV), en el Museo Rolin de Autun ${ }^{96}$, apuntala la hipótesis de la existencia de un prototipo común borgoñón, quizás desaparecido o que no he podido localizar.

San Juan Bautista gozó de gran devoción en Borgoña, como demuestran las numerosas representaciones que han llegado hasta nosotros. Habría que destacar las dos situadas en las capillas del oratorio ducal -baja y alta-, ambas desaparecidas, pero cuya huella puede rastrearse en su descendencia. De la primera, citada por la documentación en 1390 y atribuida a Jean de Marville ${ }^{97}$, nos han llegado dos fragmentos, que han permitido a los especialistas sostener que fue imitada por el San Juan Bautista de Rouvres, ejecutado por Juan de la Huerta hacia 1445-1448 ${ }^{98}$.

figs. 300-3005; para la de Berlín: G. TROESCHER, Claus Sluter und die burgundische Plastik um die Wende des XIV Jahrhunderts, Freiburg im Breisgau, 1932, p. 98, lámina XXIV a. Con excepción de una de las de Flavigny y de la del Museo de Berlín las restantes están emparejadas con el correspondiente San Juan Evangelista.

94 Vid. bibliografía citada en nota anterior.

95 P. QUARRÉ, op. cit., 1976, nº 35-37, pp. 41-42.

96 P. QUARRÉ, La sculpture à Bourgogne à la fin du Moyen Âge, Friburgo-París, 1978, nº 54, p. 109.

97 Marville muere en 1389, pero la estatua debía estar terminada antes.

98 P. QUARRÉ, "Les statues de l'oratoire ducal à la Chartreuse de Champmol”, Recueil publié à l'occasion du cent cinquentenaire de la Societé Nationale des Antiquaires de France, 1955, pp. 245-255, especialmente 247, 249-250. 
La segunda no se menciona en la documentación de modo expreso, pero se ha deducido su existencia a partir del hallazgo de una serie de restos, suponiéndose que formaba parte de un grupo de tallas, aludidas de modo genérico en un documento de 1393, adjudicándola con más vacilaciones también a Marville y planteando la posibilidad de que una escultura conservada en la Pierpont Morgan Library de Nueva York, datada c. 1450 , sea reflejo suyo ${ }^{99}$. La estatua navarra ha sido relacionada con esta última ${ }^{100} \mathrm{y}$, ciertamente, se encuentra más cerca de ella que de la de Rouvres -coinciden en el brazo desnudo, la introducción de la túnica de piel y el detalle del cordero colocado directamente sobre la mano sin la intermediación de un libro-, pero hay también diferencias que conciernen especialmente a la edad del personaje -un hombre maduro en el ejemplo de Pamplona y un anciano en el de Nueva York-, al tratamiento del cabello y barba -más cortos en Pamplona- y a la disposición del manto; de todas maneras su filiación borgoñona es innegable. Desgraciadamente, hemos perdido la imagen del Precursor labrada por Lome en 1411 con destino al palacio de Olite, muy posiblemente su primera realización navarra ${ }^{101}$, que sin duda hubiera arrojado luz sobre el tema.

En cuanto a San Antonio Abad y Santa Catalina ${ }^{102}$, sus esculturas figuraban igualmente en el oratorio ducal de Champmol ${ }^{103}$. Del primero, terminado para 1390 y obra de Marville, no nos ha llegado nada, aunque se ha planteado la hipótesis de que una serie de tallas de procedencia borgoñona, muy similares entre sí y datadas a partir de mediados del XV, deriven de él: Poligny -hoy en Mouthier-Vieillard-, Museo de Cluny, Thoisy-le-Desert y Manlay ${ }^{104}$. Pero la versión navarra resulta diferente, más rica, gracias al giro de la figura hacia la izquierda y a la compleja colocación del manto. De la segunda, ejecutada con anterioridad a 1393, se han conservado algunos vestigios, de los que se deduce que portaba libro y espada, pero que nosotros sepamos, nadie hasta el momento ha identificado una posible

99 Ibidem, pp. 253-254; y K. MORAND, op. cit., 1991, pp. 325-326. Sobre las vacilaciones a la hora de atribuir el presunto modelo a un artista determinado - perfectamente explicables por los escasos restos que nos han llegado- son muy significativas las palabras de esta autora referidas al ejemplar de la Pierpont Morgan: "may reflect Marville's lost statue in a style modified by Sluter's later work at Champmol". De sus palabras se deduce que la estatua original era de Marville, pero que Sluter habría hecho otra versión, adaptada a su estilo, también para Champmol, que sería el auténtico prototipo de la talla de la Pierpont.

${ }^{100}$ G. TROESCHER, op. cit., 1940, p. 104. Por entonces el ejemplar norteamericano pertenecía a la colección Warburg y de ahí que Troecher bautizara esta tipología como tipo Warburg.

${ }^{101}$ R.S. JANKE, op. cit., 1977, p. 38 y apéndice 1411, 1 y 2. Algunos autores interpretan que se trata de un relieve, pero los documentos hablan de una imagen.

${ }^{102}$ La relación de estas imágenes con Sluter y con la escultura borgoñona fue apuntada también por G. TROESCHER, op. cit., 1940, pp. 114 y 170, aunque sin mencionar paralelos concretos.

${ }^{103}$ P. QUARRÉ, op. cit., 1955, pp. 245-255, especialmente pp. 247 y 252-253; y K. MORAND, op. cit., 1991, pp. 322, 324 y 325.

${ }^{104}$ S.N. FLIEGEL y S. JUGIE, op. cit., 2004, p. 240, no 108, p. 277 -Poligny-, no 130, p. 337 -Museo de Cluny-; y P. QUARRÉ, op. cit., 1978, nº 70, p. 131 -Thoisy-le-Desert- y n 76, p133 -Manlay-. La única con datación anterior sería la de Cluny, que se sitúa en el primer cuarto de la centuria. La de Poligny ha sido atribuida al taller de Juan de la Huerta y la de Manlay a Antoine Le Moiturier. 
secuela. En todo caso el ejemplo pamplonés -quizás la pieza más notable del conjunto por su delicadeza- parece moverse en la órbita de Claus de Werve ${ }^{105}$.

La estatua de Dios Padre, que corona el sepulcro, puede relacionarse con varias esculturas del mismo personaje, pero que formaban parte de un grupo, la Trinidad erguida -una iconografía muy original, apenas empleada con anterioridad-, como las de Genlis, capilla de la Santa Cruz de Jerusalén del Hospital General de Dijon, Museo de Dijon y Museo de Houston ${ }^{106}$, uno de cuyos rasgos mas característicos es el detalle del manto cubriendo la
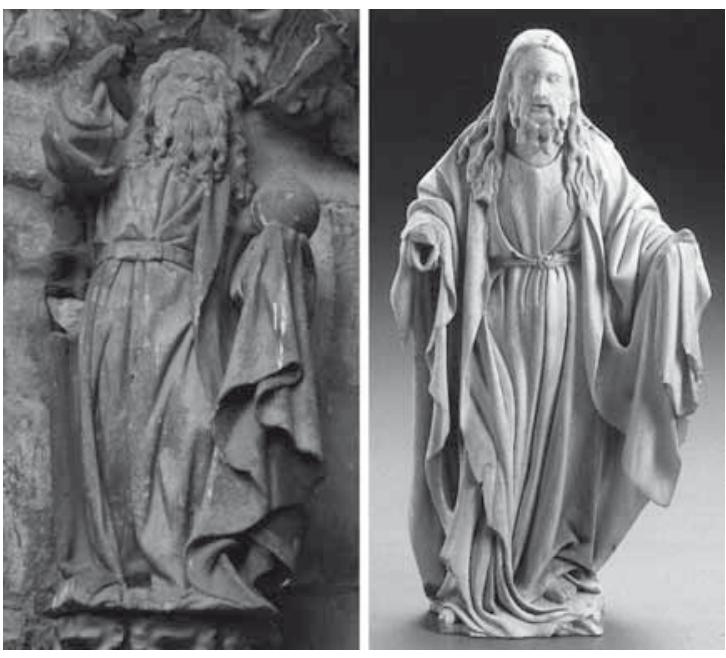

Fig. 9. Sepulcro de Leonel de Garro, Padre Eterno (izquierda). Dios Padre de un grupo de la Trinidad (Museo de Houston) (derecha).

mano izquierda de Dios, como en nuestra imagen, algo considerado, a su vez, como exclusivamente borgoñón (fig. 9). Se piensa que todas son "copias" de la desaparecida Trinidad que presidía el altar mayor de la Cartuja de Champmol -dedicada precisamente a la Trinidad-, ejecutada por Jean de Marville y terminada para 1388.

Un examen visual demuestra que estas esculturas de la tumba navarra poseen idénticos rasgos formales y son obra del mismo artífice, como se advierte especialmente en el tratamiento de las vestiduras, en particular de la parte inferior cayendo largamente sobre la peana. De otro lado, un cotejo pone de manifiesto que estamos ante una mano diferente de la que talló las efigies del mismo sepulcro y los yacentes y la mayor parte de los plorantes de la sepultura regia -todos ellos vinculados a Lome y sus seguidores-, y cuyo estilo se ha definido recurriendo al empleo de términos como "borgoñón y sluteriano", aunque sin citar paralelos concretos ${ }^{107}$. Un rastreo cuidadoso de la plástica borgoñona ha permitido corroborar esta filiación y nos ha conducido siempre a las mismas fuentes: Jean de Marville, Claus Sluter y Claus de Werve. Nos encontramos, quizás, ante el mismo artista que labró el plorante 17 del cenotafio real, el único considerado como sluteriano, aunque no dejan

\footnotetext{
105 Tal cercanía se percibe si la comparamos con realizaciones atribuidas al artífice, como por ejemplo la Virgen Bouillot del Museo Rolin de Autun.

${ }^{106}$ I. MOSNERON-DUPIN, "Les Trinités en Bourgogne, de Jean de Marville a Jean de la Huerta. Reflexions sur l'usage des modeles dans les ateliers de sculpteurs bourguignons", Actes des Journées intenationales Claus Sluter, Dijon, 1990, pp. 193-210; K. MORAND, op. cit., 1991, pp. 327 y 329; y S.N. FLIEGEL y S. JUGIE, op. cit., 2004, p. 240.

${ }^{107}$ La única excepción en la Virgen del Calvario, respecto a la cual incluye la opinión Liebreich sobre su derivación de su equivalente del Calvario de la Cartuja de Champmol -Vid. nota 92.
} 
de advertirse diferencias -la más notoria la llamativa prolongación de las vestiduras sobre la peana, que en aquél resulta infinitamente más discreta-, que impiden una total certidumbre. Por el contrario, lo que sí parece seguro es que este escultor intervino también en la puerta de San José.

\section{La Puerta del crucero Norte o Puerta de San José ${ }^{108}$}

Se trata de una obra no documentada, pero que ya de antiguo ha sido relacionada con Lome y su taller, sobre la base del análisis estilístico, concretamente de los parecidos entre los santos de sus arquivoltas y los plorantes de la sepultura de Carlos III $^{109}$. Por nuestra parte, intentaremos demostrar que los contactos con las realizaciones de Lome y su círculo no se agotan en la tumba regia.

Los lazos con ésta han llevado a considerarla poco posterior a ella, apuntándose una datación hacia $1425^{110}$. Sin embargo, recientemente, se ha retrasado la fecha a la segunda mitad de la década, entre 1425 y 1429, apoyándose en la interpretación del programa de su tímpano, la Coronación de la Virgen, a la luz de un hecho histórico, la coronación de la reina propietaria de Navarra, doña Blanca, que ascendió al trono en 1425 -tras el fallecimiento de su padre Carlos III-, pero retrasó la ceremonia hasta $1429^{111}$.

La puerta está constituida por un vano de arco apuntado abocinado con dos arquivoltas, inscrito en otro conopial rematado en doble florón. El conjunto se encuentra flanqueado por sendos pináculos, cuya parte inferior hasta la altura del dintel está dispuesta en ángulo y moldurada, y a partir de ahí presentan hornacinas coronadas por doseles, sobre los que se elevan los remates piramidales. Sobre éstos y el florón del arco conopial corre una moldura horizontal decorada con figuras de animales que completa el encuadre. El ápice del arco apuntado está ocupado por un tímpano, sustentado por ménsulas.

El centro del programa escultórico es la Coronación de la Virgen, que campea sobre el tímpano ${ }^{112}$, integrada -según fórmula usual- por las figuras de María y

${ }^{108}$ El nombre de puerta de San José, con el que se le conoce generalmente y que incluso ha sido adoptado por la plaza a la que se abre, lo ha tomado del retablo de este santo, que estaba emplazado en el crucero norte, al que da acceso, y no tiene la menor relación con su iconografía.

${ }^{109}$ E. BERTAUX, op. cit., 1908, p. 109 la atribuye a los discípulos de Lome y R.S. JANKE, op. cit., 1977, p. 107 a Lome y su taller.

${ }^{110}$ Ibidem, pp. 112-113.

${ }^{111}$ J. MARTÍNEZ DE AGUIRRE, "El honor de la corona: los encargos artísticos de la reina Blanca de Navarra (1425-1441)”, Goya, 334 (2011), pp. 15-21.

${ }^{112} \mathrm{Su}$ estado de conservación deja que desear. Faltan las manos de María -aunque puede deducirse cual era su ademán a partir de la posición de los brazos-, la cabeza de ambos ángeles y el instrumento musical del de la derecha. Lo más deplorable es el hecho de que en las fotos incluidas en el libro de R.S. JANKE, op. cit., 1977, fig. 62, publicado en 1977, el ángel de la izquierda aún conservaba la cabeza, sin que por lo visto nadie la echara en falta, ni dijera nada al respecto. 

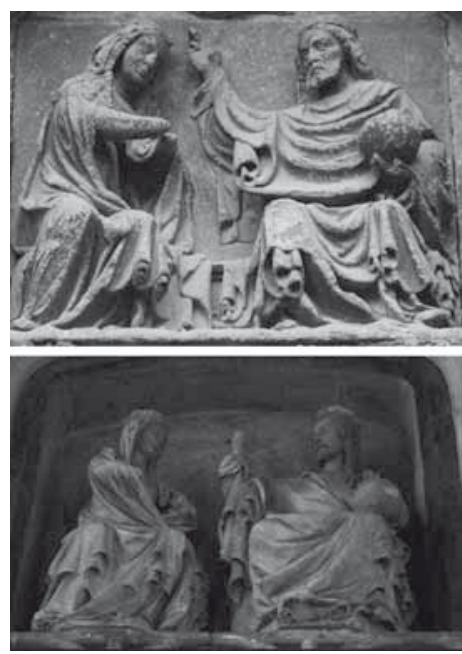

Fig. 10. Catedral de Pamplona, Puerta del crucero norte, tímpano: Coronación (arriba). Iglesia de Saint Jacques de Liège, Puerta: Coronación (abajo).

Cristo Cosmócrator, ambos sedentes en el mismo banco y con el cuerpo girado tres cuartos la una hacia la otra. La Virgen, ya coronada, en actitud orante con las manos unidas, recibe la bendición de su hijo, que en la mano izquierda ostenta el orbe. El grupo se encuentra flanqueado por sendos ángeles músicos genuflexos, ligeramente vueltos hacia el centro, y sobre sus cabezas flota una cabeza de serafín.

El interés de esta escena radica, especialmente, en su semejanza con la Coronación, que preside la puerta de la iglesia de Santiago de Lieja (h. 1390$1400)^{113}$, tan estrecha que invita a pensar que el autor la conoció personalmente (fig. 10). En este sentido, resulta significativo que recientemente se haya apuntado la posibilidad de que Lome fuera nativo de la localidad homónima -Lomme- ${ }^{114}$, cercana a Lieja ${ }^{115}$. Pero es que además la portada belga tuvo eco, como acredita el grupo de la Coronación del Museo de Arte Religioso de Gray (h. 1400) -procedente de Velloreyes-les-Choyes-, que se ha colocado en la órbita de Marville ${ }^{116}$, lo que nos obliga a plantearnos la posibilidad de que la vía de acceso al modelo fuera alguna obra de este escultor desaparecida, si bien el ejemplar de Lieja le queda más cercano.

La decoración plástica continúa en las arquivoltas, en las que se desplegaban dieciocho figuras de santos, varones, en pie y girados hacia el tímpano, para contemplar la escena, aunque actualmente faltan las cuatro inferiores ${ }^{117}$. En la exterior, de abajo arriba y de izquierda a derecha, encontramos un personaje con cabellera y barba largas, ataviado con túnica y manto, portando un libro abierto en la izquierda ${ }^{118}$; San Antonio abad, identificable por el hábito y el bastón en tau en el que apoya su mano izquierda mientras con la diestra sujeta un volumen; un obispo, con capa pluvial y mitra, llevando el báculo en la diestra y un libro abierto en la izquierda -quizás San Luis de Tolosa, a juzgar por la presencia del cordón franciscano ${ }^{119}$-; un canónigo; San Clemente Papa, con el bordón remata-

${ }^{113}$ R. DIDIER, op. cit., 2003, p. 473.

114 J. MARTÍNEZ DE AGUIRRE, op. cit., 2009, p. 394.

115 Actualmente es un suburbio de la ciudad.

${ }^{116}$ R. DIDIER, op. cit., 1993, p. 27; y S.N. FLIEGEL y S. JUGIE, op. cit., 2004, no 21, p. 69.

${ }^{117}$ Varias están muy afectadas por la erosión y han perdido las manos y los atributos, lo que complica la identificación y el análisis estilístico.

${ }^{118}$ Quizás llevaba otro objeto en la diestra, pero lo ha perdido junto con la mano.

${ }^{119}$ La única duda es que en principio parece que se le representa siempre imberbe. 
do por cruz y el ancla, que nos permite reconocerlo; otro obispo, éste con casulla, bendiciendo con la diestra y portando en la izquierda un objeto muy perdido -¿un báculo?-; san Francisco, mostrando los estigmas; otro obispo, muy similar al primero -salvo por la carencia del cordón franciscano-, pero en posición invertida ${ }^{120}$. En la arquivolta interior, siguiendo el mismo orden, vemos a San Lorenzo ${ }^{121}$, con ropaje de diacono, sosteniendo la parrilla con la diestra y llevando en la izquierda un par de libros; un obispo cefalóforo, posiblemente San Nicasio, de gran devoción en Navarra, especialmente entre la familia real; San Sebastián, con túnica a media pierna y manto, apoyando la diestra en una espada y empuñando en la izquierda su atributo, un haz de flechas; $y$, finalmente, otro dos santos diáconos y sin duda mártires, prácticamente idénticos a San Lorenzo, pero con la postura invertida, portando libros, el último posiblemente San Esteban a juzgar por la piedra sobre su hombro derecho ${ }^{122}$.

Las ménsulas que sustentan el tímpano llevan esculpidos sendos ángeles sedentes mostrando escudos, que, al parecer, ostentaban las armas reales, aludiendo a los promotores ${ }^{123}$. Se ha hecho notar que a partir de aquí se difunde en el arte navarro el recurso a las figuras de ángeles en ménsulas como tenantes de escudos ${ }^{124}$, pero podríamos también preguntarnos si no nos encontramos de nuevo ante una idea tomada de la Cartuja de Champmol, cuyo oratorio ducal en la capilla inferior contaba con una repisa decorada con ángeles llevando las armas de los duques, elemento además lo suficientemente llamativo como para dar nombre a la capilla en cuestión ${ }^{125}$, si bien es preciso reconocer que la fórmula de las ménsulas con ángeles tenantes de escudos se había empleado ya en la catedral de Tournai, supuesta patria de Lome.

En el aspecto formal, como advirtieron autores anteriores y adelantamos al principio, las estatuas de las arquivoltas están íntimamente relacionadas con los plorantes del cenotafio regio: concretamente el San Antonio con el 4; el presunto San Luis de Toulouse, el obispo emparentado con él, San Clemente y San Francisco con el 20 -también un prelado- (fig. 11); y el canónigo con sus equivalentes, los plorantes 6 y $9^{126}$. Podríamos añadir que la cabeza de serafín que vuela sobre la

\footnotetext{
${ }^{120}$ De los dos obispos que no llevan el cordón franciscano, uno podría ser san Agustín, cuya regla seguía el cabildo catedralicio pamplonés.

${ }^{121}$ La cabeza ha desaparecido.

${ }^{122}$ R.S. JANKE, op. cit., 1977, pp. 108-110 identificó correctamente a san Clemente, san Francisco, san Lorenzo, san Nicasio y san Esteban, y erróneamente a san Sebastián, del que apuntó que pudiera ser san Pablo. El resto estaban sin identificar.

${ }^{123}$ El ángel de la izquierda del espectador ha perdido la cabeza, aunque conserva el escudo, pero con las armas completamente borradas. Al de la derecha le falta el escudo. Sobre estos escudos J. MARTÍNEZ DE AGUIRRE y F. MENÉNDEZ PIDAL, op. cit., 1996, p. 247.

${ }^{124}$ Ibidem.

${ }^{125}$ K. MORAND, op. cit., 1991, p. 322.

${ }^{126}$ R.S. JANKE, op. cit., 1977, pp. 108-109, señaló los parecidos del canónigo, el presunto san Luís y san Antonio, pero no el resto.
} 

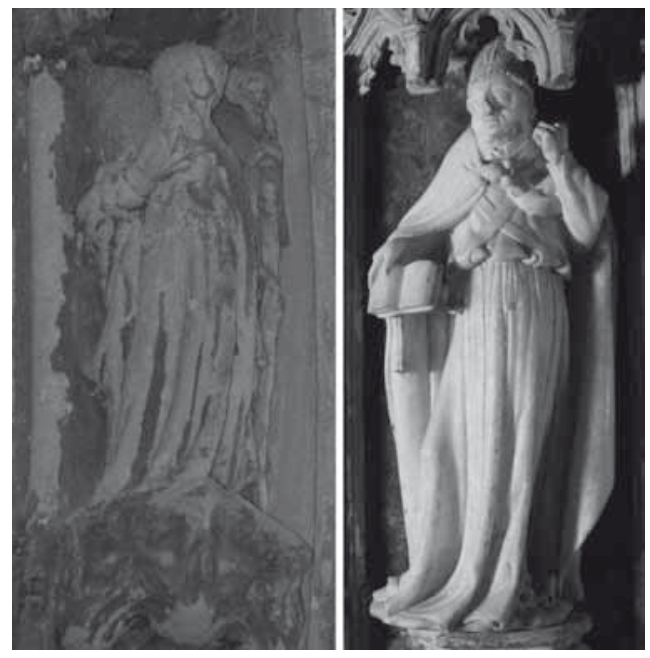

Fig. 11. Catedral de Pamplona, Puerta del crucero norte, arquivoltas, detalle: Santo obispo (izquierda). Sepulcro de Carlos III: plorante 20 invertido (derecha).

Coronación parece inspirada en la peana con el mismo asunto de uno de los plorantes, el 27. Pero, como también apuntamos al comienzo -y esto ha pasado inadvertido- los vínculos de estas figuras con las realizaciones de Lome y sus seguidores no se agotan en la sepultura de Carlos III: en efecto, el obispo ataviado con casulla y San Nicasio se asemejan mucho al yacente de la tumba del obispo Oteiza, mientras que el San Sebastián parece una versión invertida de su homónimo de Tafalla, encargado a Lome en $1422^{127}$. Finalmente y como caso aparte, cabe señalar que la cabeza del santo con larga melena y barba tiene su paralelo en la del Padre Eterno del sepulcro Garro.

A la vista de este panorama parece lógico asumir la atribución a Lome de la práctica totalidad de las esculturas de esta puerta: el tímpano y las ménsulas serían una realización personal, mientras que en las arquivoltas se podría admitir alguna intervención de sus discípulos ${ }^{128}$. Sin embargo, en el caso del santo citado en último lugar, dadas sus conexiones con el Dios Padre de la tumba Garro, atribuido a otro escultor distinto de Lome y con un estilo muy diferente, típicamente borgoñón, quizás debamos adjudicárselo.

De otro lado, las fechas de las obras relacionadas con la puerta -sepulturas de Carlos III, del obispo Oteiza y del caballero Garro, y San Sebastián de Tafalla-, quizás con la excepción de la imagen del mártir, parecen llevarnos más bien hacia la cronología temprana.

\section{La Virgen de las Buenas Nuevas}

Se encuentra adosada a un pilar del brazo del crucero sur, que alberga la escalera de caracol, de acceso a las cubiertas. Está sustentada por una ménsula decorada con el busto del rey David tocando un instrumento y flanqueado por ángeles músicos. El atributo que comparten madre e hijo, una rosa, parece moderno; probablemente el original era un pájaro. Aunque ha pasado bastante desapercibida y normalmente

${ }^{127}$ R.S. JANKE, op. cit., 1977, pp. 101-107. Dicho sea de paso esto debe disipar las dudas sobre la relación con Lome de la escultura tafallesa, que a causa de la intensa restauración y pese a estar documentada, ha sido rechazada por algunos autores -E. BERTAUX, op. cit., 1908, p. 100.

${ }^{128}$ Dada la mala conservación de muchas de ellas, resulta difícil hacer afirmaciones tajantes. 
no se incluye en el elenco de realizaciones vinculadas a Lome y su círcu$10^{129}$, resulta innegable su derivación de una famosa escultura borgoñona, la Virgen que preside el portal de la Cartuja de Champmol, labrada por Claus Sluter, tras la muerte de Marville, en $1389^{130}$. A primera vista, esta afirmación parece exagerada, debido a las diferencias
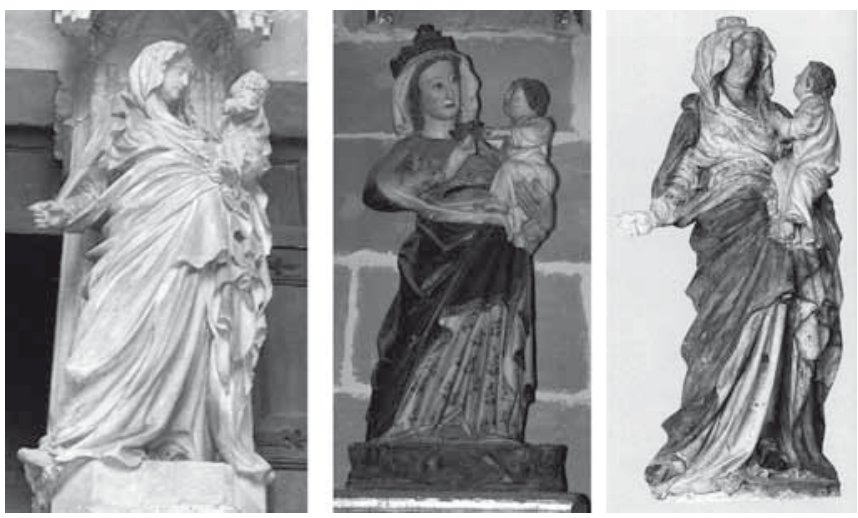

Fig. 12. Virgen de las Buenas Nuevas (centro). Vírgenes de la portada de la Cartuja de Champmol (izquierda) y de Bussy-la-Pesle (derecha). cualitativas, pero deviene más convincente si consideramos la existencia de un eslabón intermedio, como por ejemplo la talla mariana de Bussy-la-Pesle, tradicionalmente reconocida como inspirada en la de la Cartuja, que algunos autores adjudican a Claus de Werve ${ }^{131}$ (fig. 12). Por otro lado, hay constancia de que la imagen de Champmol tuvo un gran eco, como acredita la existencia de varias secuelas más, una en Sennecey y otras dos pertenecientes al Museo de Dijon y al Metropolitan Museum de Nueva York respectivamente $^{132}$. Recientemente, se ha descubierto en la iglesia de San Pedro de la Rúa de Estella una estatua del mismo tipo, en tamaño reducido, desgraciadamente bastante dañada -por lo pronto han desaparecido las cabezas-, que quizás haya que poner en relación con el sepulcro de los mariscales de Navarra en la citada iglesia, aunque la fecha que se da para esa tumba (posterior a 1449) nos parece demasiado tardía para la escultura mariana ${ }^{133}$.

Desde luego se trata de una obra plenamente borgoñona, pero su inferior calidad nos inclina a descartar que estemos ante el mismo artífice de las figuras de santos del sepulcro Garro.

${ }^{129}$ La monografía de R.S. JANKE, op. cit., 1987, no la cita. La mención, con referencia a la vinculación con los ejemplares de Champmol y Bussy-la-Pesle en C. FERNÁNDEZ-LADREDA, Imaginería medieval mariana (en Navarra), Pamplona, 1989, pp. 313-314.

${ }^{130}$ S.N. FLIEGEL y S. JUGIE, op. cit., 2004, pp. 175 y 177.

${ }^{131}$ G. TROESCHER, op. cit., 1932, p. 106; J. BOCCADOR, La statuaire medievale en France de 1400 à 1530, I, Zoug, 1974, p. 199; P. QUARRÉ, op. cit., 1976, nº 39, pp. 42-43; y S.N. FLIEGEL y S. JUGIE, op. cit., 2004, nº 86, pp. 244.

${ }^{132}$ S.N. FLIEGEL y S. JUGIE, op. cit., 2004, p. 239. La del Metropolitan fue vinculada con la de Chapmol por G. TROESCHER, op. cit., 1932, pp. 79-90 y, a diferencia del modelo y de los restantes ejemplares, lleva al niño sobre el costado derecho. Las del Museo de Dijon y Sennecey por P. QUARRÉ, op. cit., 1976, n 39 y 40 , pp. $42-43$.

133 J. MARTÍNEZ DE AGUIRRE y F. MENÉNDEZ PIDAL, op. cit., 1996, pp. 144-145. 